\author{
Federal Reserve Bank of Dallas \\ Globalization and Monetary Policy Institute \\ Working Paper No. 286 \\ http://www.dallasfed.org/assets/documents/institute/wpapers/2016/0286.pdf
}

\title{
FDI and the Task Content of Domestic Employment for U.S. Multinationals*
}

\author{
Alexis Grimm \\ Bureau of Economic Analysis \\ Mina Kim \\ Bureau of Labor Statistics
}

September 2016

\begin{abstract}
Using a unique dataset, we examine how the foreign direct investment activities of U.S. multinational manufacturers are related to the composition of their domestic employment. The analysis is based on a dataset in which Bureau of Economic Analysis (BEA) firm-level data on the foreign operations of U.S. multinationals are matched with Bureau of Labor Statistics (BLS) establishment-level data on occupation and wage distributions. The main implication of our findings is that foreign direct investment is generally positively correlated with domestic labor demand, with automated/routine tasks representing an important exception. For firms that export a significant amount to their foreign affiliates for further processing, foreign labor in low-income countries appears to substitute for domestic labor in automated/routine tasks. Our results show that these firms tend to be younger and smaller. They do not seem to be more engaged in innovative activity at home compared to other multinational manufacturers in our sample.
\end{abstract}

JEL codes: F23, F16

\footnotetext{
* Alexis Grimm, Bureau of Economic Analysis, 4600 Silver Hill Road, Washington, DC 20233. 202-6069696. alexis.grimm@bea.gov. Mina Kim, Bureau of Labor Statistics, Postal Square Building, Rm 3105, 2 Massachusetts Avenue, NE, Washington, DC 20212. 202-691-6596. minakim@mkecon.com. An earlier version of this paper was circulated as "Domestic Employment Characteristics and the Global Engagement of U.S. Multinational Manufacturers." The views in this paper are those of the authors and do not necessarily reflect the views of the U.S. Bureau of Economic Analysis, the Bureau of Labor Statistics, the Federal Reserve Bank of Dallas or the Federal Reserve System.
} 


\section{Introduction}

As U.S. firms become more globally engaged, policymakers and researchers have been greatly interested in the domestic impact of their overseas activities. In particular, questions remain as to how foreign direct investment (FDI) relates to labor demand, wages, and the job polarization phenomenon recently seen in the United States. ${ }^{1}$ While U.S.-based multinationals comprise less than $1 \%$ of all companies in the U.S., their value added was $20.4 \%$ of GDP in 2004, and they employed $18.6 \%$ of the domestic workforce in the same year. ${ }^{2}$ Thus, it is important to understand how the global activities of these large and important companies are related to their domestic operations.

This paper is the first to use a dataset in which the foreign activities of a U.S. multinational are linked to its domestic employment characteristics. Specifically, for each firm, we have information on its foreign operations, as well as the number of domestic employees in each occupation and the wage distributions within each occupation. With this rich information, we are able to shed some light on the domestic employment characteristics of these multinationals, which are quite heterogeneous in their organizational structures and their global activities. We document how the FDI activities of U.S. multinational manufacturers are related to their domestic employment characteristics across different types of labor tasks. In other words, we examine if firms that engage in more of a particular type of FDI employ more of a particular type of labor task domestically. Given that these firms can and do engage in vastly different activities, we should expect the allocation of domestic tasks to reflect that heterogeneity.

To answer this question, occupations are categorized based on task content, rather than skill, since we are interested in defining occupations based on their offshorability (i.e. tradeability). ${ }^{3}$ As pointed out by Criscuolo and Garicano (2010), we think that

\footnotetext{
${ }^{1}$ Job polarization refers to declining opportunities for middle-skilled workers, while demand for high- and low-skilled workers increases. See Autor (2010) and Jaimovich and Siu (2012).

${ }^{2}$ These statistics are for non-bank U.S. parents compared to private industry GDP and employment. GDP, value-added, and employment numbers are obtained from BEA's interactive data website: http://www.bea.gov/itable/index.cfm.

${ }^{3}$ Following Blinder (2009), we define offshoring as the location of production abroad, as opposed to
} 
characterizing occupations according to their task content can better capture the ability to move a particular job abroad. Occupations may require the same skill level even though they are not equally tradeable. Therefore we consider each occupation's composition as it relates to two types of tradeable tasks, those related to automation/routine-ness and those reliant on information technology. We also consider non-tradeable tasks related to face-to-face interaction.

We make a number of observations about the domestic employment characteristics of U.S. multinational manufacturers. First, we find that in firms with more expansive global scope, foreign and domestic labor are complements. This result is based on a firm-level index of global scope that not only takes into account the level of FDI, but also the location of FDI, such that more weight is given to FDI in countries that are further away in income. Of particular interest is the demand for tradeable tasks. For the firm with global scope in the 75th percentile, a one percent fall in the price of foreign labor is accompanied by an increase in the demand for domestic automated/routine tasks that is 4.6 times larger than that for the median firm. ${ }^{4}$ On the other hand, the difference in demand for domestic information content-related tasks is smaller; a one percent fall in the price of foreign labor is accompanied by an increase in demand that is 2.6 times larger than that for the median firm.

For firms with limited global scope, we find that foreign labor and domestic automated/routine tasks are substitutes. We explore this result further and examine specific parent-foreign affiliate relationships based on the type and location of intrafirm trade. We find that more intrafirm trade with high-income countries is positively correlated with domestic employment in tradeable tasks. However, foreign labor and domestic automated/routine tasks seem to be substitutes, depending on the amount and type of offshoring in which they are engaged. More specifically, we find that for firms that export a significant amount of goods to their foreign affiliates for further processing, higher foreign employment in low-

outsourcing, which we define as the contracting out of production to an arms-length party.

${ }^{4}$ Note that we find that foreign labor and domestic automated/routine tasks appear to be complements for the median firm. 
income countries is accompanied by lower domestic employment for automated/routine tasks. On the other hand, for firms importing a significant amount of goods from their foreign affiliates, demand for foreign labor in low-income countries appears to be complementary to domestic demand for automated/routine tasks, and tradeable tasks in general.

Together, these new insights suggest that the domestic impact of FDI depends on the relative allocation of FDI across the different types and locations. Our results are consistent with the notion that multinational manufacturers adjust the composition of their domestic labor force in ways that are related to the composition of their FDI activity. The nuances have become important to understand especially given the recent resurgence of antiglobalization sentiments. U.S. multinationals have been painted as "disloyal" and largely responsible for the loss of U.S. manufacturing jobs. ${ }^{5}$ The substitution of foreign labor for domestic labor has become the focus of this anti-globalization movement, so we further examine which type of multinational manufacturers might be involved in such substitution.

Our results show that the firms that appear to substitute foreign labor in low-income countries for domestic automated/routine tasks are the firms that engage in more offshoring to their foreign affiliates. While this result might be intuitive, these firms play a relatively small role in the global economy. We find that these firms comprise of just $1 \%$ of sales in our sample. Furthermore, the offshoring firms tend to be younger, on average, and smaller. Domestically, these firms tend to employ fewer workers in innovation-related occupations. There is no statistically significant difference in wages between the firms that do substitute automated/routine tasks with foreign labor and those firms that do not.

The rest of the paper proceeds as follows. Section 2 describes the related theoretical and empirical literature. Section 3 describes the data, while Section 4 explains how we map occupations into tasks. Section 5 documents our findings related to labor demand. Section 6 provides a preliminary analysis of how firms differ with regard to their offshoring activities. The last section concludes the paper.

\footnotetext{
${ }^{5}$ See the recent editorial by Robert J. Samuelson (https://www.washingtonpost.com/opinions/thelargely-false-globalization-narrative/2016/08/07/7a095582-5b25-11e6-9aee-8075993d73a2_story.html?hpid=hp_noname_opinion-card-a\%3Ahomepage\%2Fstory).
} 


\section{Related Literature}

This paper contributes to the literature on the employment effects of multinational activity. The theoretical literature has largely focused on two main motives for extending production outside of national borders: vertical versus horizontal integration. Predictions about the relationship between FDI and domestic labor depend on the motivation for FDI as well as the assumptions of the model. ${ }^{6}$

Empirical results have also been mixed (see Brainard and Riker (2001) and Desai, Foley, and Hines (2009), for example). Harrison and McMillan (2011) find that the lack of agreement in the previous literature regarding the degree of complementarity between foreign and domestic labor can be explained by taking into account the type and location of FDI. Our empirical strategy is closely related to Harrison and McMillan (2011) in that we address the direct displacement of workers due to FDI by conditioning on output prices. However, following the more recent trend in the literature, we improve upon their study by trying to determine which workers might be displaced.

As microdata become available, more empirical studies are beginning to examine these effects at the occupation or task level. For Japan, Head and Ries (2002) find that more overseas employment in low-income countries is related to more domestic employment of non-production workers, but they also find that this relationship deteriorates as the income of the destination country rises. Tomiura et al. (2011) look at more detailed information on worker skill in Japanese multinationals and finds that the share of skilled non-production workers is high in offshoring Japanese firms. More recent empirical work by Becker et. al (2013) finds that German multinationals engaging in more offshoring employ more workers in non-routine tasks domestically. Hakkala et al. (2013) conclude that Swedish multinationals have a high share of non-routine tasks and tasks requiring personal interaction in the home country.

This paper also contributes to the more general literature on offshoring. Hummels et al. (2016) provide a recent survey of the extensive empirical literature. As with the

\footnotetext{
${ }^{6}$ See Antras and Yeaple (2014) for a summary of the literature.
} 
multinational literature, more recent papers have focused on the impact of offshoring across different types of workers. In their seminal work, Grossman and Rossi-Hansberg (2008) model the fragmented production process of a firm as a series of labor tasks that have different costs to being moved abroad. Employment and wage effects depend on the relative sizes of productivity gains, worker displacement, and market power. In their model, as firms are better able to fragment production and relocate tasks where they are performed most cost effectively, there is a positive productivity effect that may result in an expansion in overall production. This productivity effect, in turn, may lead to an economy-wide increase in labor demand - even for the type of labor that is offshored. Bernard et al. (2016) find that for Danish firms, more offshoring leads to higher employment of technical occupations at home.

This study is the first to use disaggregated data at the occupation level for U.S. multinationals. Doms and Jensen (1998) look at the difference between production and nonproduction workers based on the multinational status of firms. However, their definition of production workers includes a wide range of non-supervisory workers involved in a production plant, and is of limited value in differentiating workers/jobs based on skill level or task content. Slaughter (2001) also examines the difference between production and nonproduction workers, but notes that the results are based on estimates of production vs. non-production employment at the parent.

Other papers attempt to infer the task distribution of U.S. employment by applying task definitions at the industry or two-digit occupation level. ${ }^{7}$ Even at disaggregated levels of industry, heterogeneity across firms within a sub-industry has been well documented (Davis and Haltiwanger, 1991 and Baily et al., 1992). Equally problematic is analysis at the two-digit occupation level, as the types of occupations within a two-digit occupation code can be highly heterogeneous with regard to job characteristics. ${ }^{8}$

\footnotetext{
${ }^{7}$ For example, see Oldenski (2012), Blinder (2009), or Jensen and Kletzer (2010). Note that Autor et al. (2013) uses the Census classification system for occupations, which is not as detailed as the Standard Occupational Classification system, but still detailed enough that this remark probably does not apply.

${ }^{8}$ For example, Standard Occupational Classification code 27 includes photographers, interpreters, news analysts, athletes, and actors. See Becker et al. (2013) for an example using German data.
} 


\section{Data}

\subsection{Multinationals and Occupations}

We use a unique dataset in which a sample of U.S. multinational firms identified in BEA's 2004 Benchmark Survey of U.S. Direct Investment Abroad is matched with establishmentlevel employment data collected by BLS. ${ }^{9}$ For the 2004 Benchmark Survey of U.S. Direct Investment Abroad, every U.S. parent company with a foreign affiliate was required to report information for itself and each of its foreign affiliates. ${ }^{10}$ The financial and operating data include balance sheets and income statements; property, plant, and equipment; employment and compensation of employees; U.S. trade in goods; sales of goods and services; value added; research and development activities; taxes; and external financial position.

Handwerker et al. (2011) attempted to identify all establishments of the 500 largest multinational manufacturers in BLS's Quarterly Census of Employment and Wages (QCEW) for years 2004 and 2005. They were able to find adequate matches for 453 of these 500 firms, covering over 5.6 million workers. ${ }^{11}$ The establishments of these 453 firms were then linked with the establishment-level microdata of BLS's Occupational Employment Statistics (OES) survey panels from November 2003 to May 2006. Due to the OES sample design, which includes all large establishments with certainty over this three-year panel as well as smaller establishments sampled probabilistically, about one-fifth of the establishments that we were able to identify in the QCEW are also part of the OES sample and responded to the OES surveys between November 2003 and May 2006. Establishments surveyed in the OES report the distribution of their employees' occupations by the 801 detailed civilian occupations of the Standard Occupational Classification (SOC) system along with hourly

\footnotetext{
${ }^{9}$ See Handwerker et al. (2011) for details about the match.

${ }^{10}$ For more details, see U.S. Bureau of Economic Analysis. U.S. Direct Investment Abroad: 2004 Final Benchmark Data. Washington, DC: U.S. Government Printing Office, November 2008 (http://www.bea.gov/international/usdia2004f.html).

${ }^{11}$ A firm is considered to be "adequately-matched" to BLS establishment data if the total employment of all matched BLS establishments for a particular firm is within $20 \%$ of the total employment reported in the BEA survey. The matched establishments are likely not a random sample of their establishments. As described in Handwerker et al. (2011), matching methods focused disproportionately on finding the largest establishments for these firms.
} 
wages in 12 broad wage bands. ${ }^{12}$

\subsection{The Estimation Sample}

Our estimation sample of 453 firms contain $84 \%$ of the employees of multinational manufacturers based in the United States (see Table 1).

As theory would predict, the firms in our sample are larger and more productive than the average multinational. The top panel of Table 2 shows the average employment, employee compensation, value added, labor productivity, and sales for our sample compared to the average values for all multinationals. The bottom panel of Table 2 shows the same variables across non-bank foreign affiliates of these firms. The average firm in our sample hires more workers abroad, with more value added per worker than the average multinational. However, the distribution of firms across industries and countries is fairly representative of all the multinationals operating in 2004. Across industries, the distribution is slightly more skewed towards petroleum and coal products and transportation equipment in our sample compared to the universe of multinationals, while the distribution of foreign affiliate activity across countries is similar. (See Appendix B.)

Our sample of multinationals is quite heterogeneous in terms of their international activity. They accounted for $84 \%$ of the total exports of goods by U.S. multinational manufacturers and $90 \%$ of the total imports of goods by U.S. multinational manufacturers in 2004 (see Table 3). However, some of these firms only exported or only imported, and some did not trade at all. About $11 \%$ of the firms did not export and $22 \%$ of the firms did not import, while $9 \%$ neither exported nor imported.

About $88 \%$ of the firms in our sample also engaged in intrafirm goods trade with their foreign affiliates at varying levels. Nearly $45 \%$ of their exports were exports to foreign affiliates, while nearly $57 \%$ of their imports were sourced from their foreign affiliates. Almost

\footnotetext{
${ }^{12}$ As with any survey, there are a number of non-respondents for which the data are imputed. Imputed data comprise about $40 \%$ of the employment total. To account for the non-surveyed, the data are weighted using the benchmark weights, which are designed to account for sampling probabilities and other factors, such that the data represent the universe. Weighted data account for about $7 \%$ of the employment total. See Appendix A for more information about the weights and imputations.
} 
$60 \%$ of the exports to foreign affiliates were for further processing by the affiliates in our sample, compared to $55 \%$ for all affiliates. These numbers seem consistent with the more recent shift by multinationals toward fragmenting production across the U.S. and abroad.

A description of the domestic operations of the sampled firms is given in Handwerker et al. (2011). Although the primary industry of sales of these U.S. parent companies is manufacturing, their domestic establishments span a wide variety of industries. Not surprisingly, these establishments employed most of their workers in the manufacturing industry. Within manufacturing, they employed most workers in the transportation equipment manufacturing and computer and electronic manufacturing sub-industries. Wages in these manufacturing establishments were highest for those in the professional, scientific, and technical services and the management of companies and enterprises services industries.

\section{Occupations and Tasks}

The OES provides us with establishment-level measures of domestic employment and wages for each of hundreds of detailed occupations. We follow the recent literature (Autor et al., 2003; Jensen and Kletzer, 2010; Blinder, 2007; and Firpo et al., 2011) in identifying the task composition of these occupations To do so, we use the "occupational requirements" elements in $\mathrm{O}^{*}$ net, a comprehensive database describing each occupation in great detail. In particular, we are interested in three of the tasks that Firpo et al. (2011) deem to be the most relevant measures of offshoring potential and technological change. First, the "information content" index measures the extent to which an occupation involves communications technologies and thus be more easily traded. Second, the "automation/routinization" index measures the degree to which an occupation involves manual and routine activities, which are considered to be highly tradeable. Third, the "face-to-face" index measures the extent to which a job requires a worker's physical presence.

We calculate task-based indices for all six-digit SOC occupations in the OES using O*Net 7.0 (published in December 2004). Occupations in $\mathrm{O}^{*}$ net are defined using six measurable 
broad categories: worker characteristics, worker requirements, experience requirements, occupational requirements, workforce characteristics, and occupation-specific information. Following Firpo et al. (2011) and Jensen and Kletzer (2010), our constructed indices rely on the elements in the "occupational requirements" category, particularly the "generalized work activities" elements, which consist of both "importance" and "level" ratings, augmented with the "work context" elements, which consist of frequency scores for each work situation. In total, there are one hundred elements in $\mathrm{O}^{*}$ net that we use in measuring the task content of each occupation, and together these one hundred elements are assumed to completely describe an occupation.

For each occupation $o$, three task indexes, $I_{o h}$, are computed as in Firpo et al. (2011) one for each task $h$ described above:

$$
I_{o h}=\frac{\sum_{k=1}^{K_{h}} I_{o k}^{2 / 3} L_{o k}^{1 / 3}+\sum_{m=1}^{M_{h}} F_{o m}}{\sum_{k=1}^{K} I_{o k}^{2 / 3} L_{o k}^{1 / 3}+\sum_{m=1}^{M} F_{o m}}
$$

where $K_{h}$ is the total number of work activity elements in the task $h \in H, I$ is the standardized importance measure for element $k, L$ is the standardized level measure for element $k, M_{h}$ is the total number of work context elements in task $h, K$ is the total number of work activity elements in an occupation, $M$ is the total number of work context elements in an occupation, and $F$ is the standardized frequency measure for element $m$. The index for task $h$ in occupation $o$ is the sum of the scores for the relevant elements to task $h$ divided by the total combined score for all tasks. Each index is thus assigned a number between 0 and 1 , and $\sum_{h} I_{o h}=1$. This index can be thought to represent the intensity or importance of a task in an occupation. ${ }^{13}$

If an occupation has an index score for task $h$ that is in the 80th percentile or higher across occupations, all of the employment in that occupation is considered intensive in task $h$. Table 4 describes the average firm- and establishment-level domestic employment and wage levels for each of these tasks. Automation/routinization has the largest share

\footnotetext{
${ }^{13}$ See Appendix $\mathrm{C}$ for a list of six-digit SOC occupations that are in the top 10 and bottom 10 for each task.
} 
of average employment at both the firm and establishment level. Information content is next in its share of employment, at both the firm and establishment level. Average wages for each establishment are calculated as a weighted average of the wages at the occupation level, using employment in each occupation as weights. ${ }^{14}$ They are highest for workers in information content related tasks at the firm level. At the establishment level, wages are similar for information content related and automated/routine tasks. However, there is a great amount of variability in task-level wages across these firms and their establishments.

These data provide a "first look" at the occupational distributions of these firms that are important in our economy. No other such data providing information on both multinational activity and employment characteristics exist for U.S.-based multinationals.

\section{Domestic Employment Characteristics of Multinational Man- ufacturers}

Using various measures available in BEA's 2004 Benchmark Survey of U.S. Direct Investment Abroad, we examine the correlations between the type and extent of FDI and domestic employment patterns. We consider two different sets of variables to proxy for the extent of FDI. Our first model considers an aggregate index of FDI, capturing both the intensive and extensive margins of a firm's foreign investments using the global scope index developed in Mataloni (2011). The global scope measure is higher for firms that invest in more countries, employ more in a given country, employ more in low-income countries, and invest across more regions.

In our other second model, we differentiate between different types of FDI activity using measures of intrafirm trade. As emphasized in Hanson et al. (2001), the focus on horizontal versus vertical FDI in the literature inadequately reflects the range of global activities performed by multinationals, and we gain further insights by using measures that

\footnotetext{
${ }^{14}$ To calculate average wages in the OES data, we assign each employee a wage based on the mean wage for these wage bands, following the methods used in OES publications. The midpoints used for the wage bands in the OES are based on the exact distribution of wages in the National Compensation Survey. For more information, see http://www.bls.gov/opub/hom/pdf/homch3.pdf, page 16.
} 
describe a firms' relationship with its foreign affiliates in more detail. The extent of goods exports from a parent to its affiliates for further processing is used to represent a type of vertical FDI in which U.S. parents are offshoring parts of production to their foreign affiliates. The extent of goods exports to foreign affiliates for resale measures the type of FDI focused on distribution. In addition, the extent of goods imports from foreign affiliates is used to represent the type of vertical FDI where intermediate inputs are purchased from abroad. ${ }^{15}$ All of these intrafirm trade measures are expressed as a share of sales in our analysis.

Table 5 gives a summary of these FDI measures for our sample. ${ }^{16}$

\subsection{Domestic Employment and FDI}

To provide some structure for our analyses and for consistency with the prior literature, we examine the relationship between employment and FDI within a model of labor demand. Our specification is based on the generalization of the cost function approach in Hamermesh (1993). We assume that there are two locations, home and foreign (foreign variables are denoted with $\mathrm{a}^{*}$ ). We assume that firms in each location operate a production technology that transforms $N$ domestic factors and $N^{*}$ foreign factors into output $Y$.

Let the general production function for a U.S. multinational be:

$$
Y=f\left(X_{1}, \ldots, X_{N}, X_{1}^{*}, \ldots X_{N^{*}}^{*}\right)
$$

where worldwide output $Y$ can be produced at domestic plants or in foreign affiliates, using inputs $X$ and $X^{*}$, and can be sold in either location. One can derive the associated cost function and apply Shephard's Lemma to arrive at the demand for each factor. The factor demand for the $n$th input in each firm is then:

$$
X_{n}=X_{n}^{d}\left(w_{1}, \ldots, w_{N}, w_{1}^{*}, \ldots w_{N^{*}}^{*}, Y\right)
$$

\footnotetext{
${ }^{15}$ The type of vertical FDI represented by intrafirm imports and the type of vertical FDI represented by intrafirm exports for further processing are not necessarily mutually exclusive.

${ }^{16}$ See Appendix D for a detailed description of these variables.
} 
where $w$ and $w^{*}$ are the input prices of the $X$ and $X^{*}$ inputs.

We estimate U.S. labor demand for each domestic employment task using the loglinearized version of equation (1). This specification is flexible enough to accommodate a range of production technologies, as well as a range of inputs and locations. For our estimating equation, we further assume that $X$ includes domestic labor input across our three different labor tasks and an "other tasks" category, as well as physical capital and research and development inputs, while $X^{*}$ includes the same inputs from the foreign location. We also assume that worldwide output $Y$ is some function of domestic and foreign prices, $P$ and $P^{*}$.

The prices of final goods, capital, and R\&D are as specified in Harrison and McMillan (2011) (Appendix E provides a detailed description of the data used for each variable). Domestic wages are defined at the industry level and are the weighted averages of the May and November 2004 occupational wages published by OES. For foreign wages, we only have data on total employee compensation paid by the affiliates and number of employees, so we simplify our specification to include only average foreign wages. We also control for import competition using a measure of import penetration from Bernard et al. (2006) and firm size and age categories based on BEA data.

To investigate the correlation between labor demand and FDI, we allow the cross-price elasticity of demand to vary by the extent of FDI. Our baseline estimating equation is then:

$$
\begin{aligned}
\ln x_{f h}= & \beta_{0}+\sum_{h} \eta_{h} \ln w_{i h}+\eta^{*} \ln w_{i}^{*}+\xi\left(F D I_{f} * \ln w_{i}^{*}\right) \\
& +\omega \ln r_{i}+\omega^{*} \ln r_{i}^{*}+\chi \ln t_{f}+\chi^{*} \ln t_{f}^{*}+\alpha \ln P_{i}+\alpha^{*} \ln P_{i}^{*}+\gamma C_{f}+\varepsilon
\end{aligned}
$$

where $x_{f h}$ is employment in task $h$ for firm $f, w_{h}$ is the log domestic wage in task $h, w_{h}^{*}$ is the log wage abroad for task $h, F D I$ is our measure of the type or extent of FDI described in the previous section, $r$ is $\log$ price of capital at home, $r^{*}$ is the log price of capital abroad, $t$ is the $\log$ price of $\mathrm{R} \& \mathrm{D}$ at home, $t^{*}$ is the log price of $\mathrm{R} \& \mathrm{D}$ abroad, $P_{i}$ is the final goods price at home in industry $i, P^{*}$ is the final goods price abroad, and $C$ is a vector of control 
variables.

The coefficients of interest in equation (2) are $\eta^{*}$ and $\xi$, which gives a cross-price elasticity of demand equal to $\eta^{*}+\xi F D I_{f}$. If both terms carry the same sign, then positive coefficients would indicate that demand for foreign labor and domestic labor in task $h$ are substitutes, whereas negative coefficients would indicate that they are complements. However, if the terms carry opposite signs, then the correlation between foreign and domestic labor demand in task $h$ depends on the magnitude of FDI being carried out. There will be a level of FDI above which foreign labor and domestic task labor change from being substitutes to complements or vice versa, depending on the signs of the terms.

Given that we are estimating this model for different types of labor within a firm, it is possible that the error terms are correlated across these types. We therefore supplement our ordinary least squares (OLS) methods with seemingly unrelated regression (SUR) methods to estimate the model.

Regression results are shown in Table 6 for the baseline model described above with an aggregate measure of FDI - global scope - which is intended to capture the extensive, as well as intensive, margins of FDI. ${ }^{17}$ The global scope variable has been normalized to be between 0 and 100 in this analysis. The columns in the tables correspond with the SUR regression results for the three different tasks of interest - automated/routine tasks, face-to-face interaction tasks, and information content-related tasks - as well as all other tasks.

The coefficient on the interaction between foreign wages and global scope is negative (and significant) across all tasks. The coefficient on the foreign wage variable is also negative except in the case of automated/routine tasks. When jointly considering the coefficient on the foreign wage variables, the results indicate that substitution occurs only with domestic automated/routine tasks in firms that have limited global scope. In firms with higher global scope, FDI and domestic labor appear to be complements.

\footnotetext{
${ }^{17}$ Some firms may not employ any labor in a particular task. These observations are excluded from these regression results. However, we also re-do our analysis allowing for the employment to be censored at one. Our results are robust to such a specification.
} 
Thus, we highlight the following observation:

Observation \#1 In firms with more expansive global scope, the demand for foreign and domestic labor are positively correlated.

When taking into account that automated/routine tasks are just a fraction of total employment, this result is consistent with the previous studies that show an overall positive relationship between FDI and domestic employment (e.g. Desai, Foley, and Hines, 2009 and Kovaks et al., 2016). The results support the theories in which FDI has a positive productivity effect as these firms expand globally.

\subsubsection{Location of FDI}

While the previous analysis takes into account the income level of the destination country relative to that of the United States, Harrison and McMillan (2011), Brainard and Riker (2001), and Ekholm and Hakkala (2008) emphasize the importance of differentiating between investment in high- versus low-income countries. They show that the employment implications of FDI differ depending on where the FDI occurs.

Thus we follow Harrison and McMillan (2011) and extend the above model to disaggregate the foreign variables into those related to high-income countries and those related to low-income countries. In this extension, each firm uses $N$ domestic factors, $N^{H}$ foreign factors in high-income countries, and $N^{L}$ foreign factors in low-income countries. Log-linearizing the factor demand function for each firm gives us our second estimating equation:

$$
\begin{aligned}
\ln x_{f h}= & \beta_{0}+\eta_{h} \ln w_{i h}+\eta_{H} \ln w_{i H}+\eta_{L} \ln w_{i L}+\xi\left(F D I_{f} * \ln w_{i H}^{*}\right)+\xi\left(F D I_{f} * \ln w_{i L}^{*}\right) \\
& +\sum_{l} \omega_{l} \ln r_{i l}+\sum_{l} \chi_{l} \ln t_{f l}+\sum_{l} \alpha_{l} \ln P_{i l}+\gamma C_{f}+\varepsilon
\end{aligned}
$$

where $x_{h}$ is log employment in task $h, P_{l}$ is final goods price in location $l \in$ (home, highincome, low-income), $w_{h}$ is domestic wage in task $h, w_{H}$ is wage in high-income countries, $w_{L}$ is wage in low-income countries, $r_{l}$ is price of capital in location $l, t_{l}$ is the price of $\mathrm{R} \& \mathrm{D}$ 
in location $l$, and $C$ is a vector of control variables, which includes a measure of import penetration and a measure of import penetration from low-income countries. ${ }^{18}$

All of the variables are defined as in equation (2), except now our foreign variables differentiate between locations in high- versus low-income countries. Due to collinearity in investment and consumption prices across these locations, we keep these measures as firmlevel aggregates in our estimation, following Harrison and McMillan (2011). Additionally, to avoid dropping firms that did not invest in low-income countries, we set the variables related to foreign affiliate wages, $\mathrm{R} \& \mathrm{D}$, and import penetration equal to zero for low-income countries and include a dummy variable indicating that the firm did not invest in a lowincome country.

Table 7 shows the regression results from estimating equation (3) for the tradeable tasks using the intrafirm trade variables. Table 8 shows the regression results from estimating equation (3) for the other tasks. Since firms engage in different types of FDI simultaneously, we include all intrafirm trade variables to account for the composition of FDI. The number columns in each table correspond to the SUR regression results for the different tasks. The columns labeled (a) and (b) differ with respect to how the intrafirm variables are defined. In column (b), intrafirm trade is differentiated between those in high- vs. low-income countries, whereas, in column (a), the intrafirm trade variables do not differentiate between locations. Thus, in column (a), the cross-price elasticity is a function of the levels of the different types of FDI across all locations. On the other hand, in column (b), the cross-price elasticity is a function of the levels of intrafirm trade in each foreign location.

When allowing for the mix of intrafirm trade to affect the cross-price elasticity of demand for foreign labor, all of the coefficients on the foreign wage terms matter. The cross-price elasticity can be expressed as:

$$
\eta+\xi_{1} X_{\text {furtherprocessing }}+\xi_{2} X_{\text {resale }}+\xi_{3} M
$$

\footnotetext{
${ }^{18}$ Note that there are countries that are classified as neither high nor low income.
} 
where $X_{\text {furtherprocessing }}$ is the value of exports for further processing from a parent to its foreign affiliates as a share of parent sales, $X_{\text {resale }}$ is the value of exports for resale from parent to its foreign affiliates as a share of parent sales, and $M$ is the value of imports from affiliates to their parent as a share of parent sales.

We first examine the cross-price elasticity of demand for domestic labor with respect to foreign labor in high-income countries. In Tables 7 and 8, we see that if firms engage in no intrafirm trade, then automated/routine tasks and face-to-face tasks are negatively correlated with foreign labor in high-income countries (see columns 1a, 1b, 3a, 3b), as indicated by the positive sign on the coefficient on the log affiliate wage in high-income countries. Information content-related tasks and other tasks are positively correlated (but with no statistical significance) with foreign labor in high-income countries (see columns $2 \mathrm{a}, 2 \mathrm{~b}, 4 \mathrm{a}$, and $4 \mathrm{~b})$.

For positive levels of intrafirm trade, the location and the relative magnitudes of the different types of intrafirm trade can matter for the cross-price elasticity. Column 1a shows that more intrafirm trade, in general, is associated with complementarity between foreign labor in high-income countries and automated/routine tasks at home (although the coefficient on exports for further processing is not significant). This relationship remains even after disaggregating intrafirm trade by location (column 1b). However, for face-to-face interaction tasks, we find no significant relationship with intrafirm trade.

For information content-related tasks, we find that domestic labor tasks and foreign labor in high-income countries seem to be complementary; the coefficients on exports for resale and imports in columns $3 \mathrm{a}$ and $3 \mathrm{~b}$ are negative and the same sign as the coefficient on foreign wages in high-income countries. While the coefficient on exports for further processing is positive, it is not significant. Additionally, when calculating the cross-price elasticity of demand using the estimated coefficients for the firms in our sample, none have a positive value. This also holds for other tasks. Thus, we can say the following:

Observation \#2: More intrafirm trade with high-income countries is associated with higher demand for domestic labor in tradeable tasks. 
Given our estimated coefficients, domestic labor tasks and foreign labor in low-income countries are potentially substitutable. The substitutability depends on the magnitude of exports for further processing relative to the magnitudes of the other types of intrafirm trade. As shown in column 1a, the cross-price elasticity between domestic automated/routine tasks and foreign labor in low-income countries is positive only if the firm engages in significantly more exports for further processing than exports for resale and imports. Similarly this is the case for domestic information-content related tasks (column 2a), although the coefficient

on exports for further processing is not significant. After disaggregating intrafirm trade by location, our results become noisy, as not enough firms in our sample invest in low-income countries (columns $1 \mathrm{~b}$ and $2 \mathrm{~b}$ ).

Observation \#3: In firms engaging in a significant amount of export for further processing relative to other types of FDI, the demand for foreign labor in low-income countries is negatively correlated with domestic demand for domestic labor in automated/routine tasks.

For our non-tradeable task, column 3a indicates that the opposite relationship holds. Higher exports for further processing, with respect to FDI in low-income countries, is positively correlated with domestic demand for tasks requiring face-to-face interactions. Although the relationship is not statistically significant. One intrafirm trade is disaggregated by location (column 3b), we find that the coefficients on exports for resale and imports become significant. For firms that export less to their foreign affiliates for further processing in low-income countries, domestic face-to-face tasks are positively correlated with foreign labor in low-income countries. On the other hand, column $4 \mathrm{~b}$ shows no further information about the relationship between location or type of FDI and the demand for domestic other tasks.

By and large, the complementarity between non-automated/routine tasks and FDI is consistent with the conclusions of previous studies using data from other countries. However, our results highlight some subtleties about the employment behavior of these large, US multinationals. 


\subsection{Robustness}

\subsubsection{Intrafirm trade}

Using data on intrafirm trade from the same time period as the data on employment limits our ability to make any conclusions about the substitutability or complementarity of FDI for domestic labor. To address this endogeneity issue, we replace the simultaneous measures of intrafirm trade with the mean measures of intrafirm trade from the 1999 and 2004 Benchmark Surveys of U.S. Direct Investment Abroad. Our results are robust to the change in definition of our FDI measure, as shown in Table 9.

Table 9 shows the regression results from estimating equation (3) using the mean intrafirm trade measures. The signs of the coefficients on the foreign wage and intrafirm trade variables are the same as in Tables 7 and 8, and our highlighted observations (2 and 3) hold. ${ }^{19}$

\section{Which firms offshore more to their foreign affiliates?}

As shown above, firms that export significantly more to their foreign affiliates for further processing, relative to other intrafirm trade activities, are the firms that substitute foreign labor in low-income countries for domestic automated/routine tasks. Harrison and McMillan (2011), on the other hand, find that substitution occurs when a firm engages in a significant amount of exports for further processing in high-income countries. Our results are not necessarily contradictory, as we are examining a more select group of multinationals than in Harrison and McMillan (2011). In their study, Harrison and McMillan (2011) include many small multinationals and give them equal weight as the large firms that are in our sample. While we argue that the largest firms are the firms that drive domestic employment, there may be real differences between the firms in our sample and the average multinational.

\footnotetext{
${ }^{19}$ Note that the sample size is smaller for the regressions shown in Table 9 compared to Tables 7 and 8. There were firms that became multinationals between years 1999 and 2004 and thus were not included in this regression. Only continuing multinationals were included.
} 
In order to examine these differences, we use the coefficients shown in column 1a in Table 7, as well as equation (4), to estimate the cross-price elasticity between foreign labor in low-income countries and domestic automated/routine tasks at the firm-level. Firms that engage in enough exports for further processing such that the cross-price elasticity is positive comprise of just $1 \%$ of sales and $1.8 \%$ of $\mathrm{R} \& \mathrm{D}$ in our sample. In terms of international activity, they comprise of $1.5 \%$ of trade and $1.2 \%$ of intrafirm trade in our sample. While these firms play a relatively small role in the global economy, it is interesting to note any further differences between the firms that substitute domestic automated/routine tasks with foreign labor in low-income countries versus firms that do not.

Table 10 shows a comparison between these firms and the rest of our sample. In Table 10, we see that in firms that offshore enough to have a positive cross-price elasticity are, on average, younger and smaller (as measured by the worldwide level of employment at each firm) than those that offshore less. They employ relatively less in low-income countries compared to their employment in high-income countries. Moreover, they tend to be less diversified. The share of foreign affiliate employment in a different 3-digit NAICS code than the U.S. parent is smaller, on average, for these firms and the number of different industries in which they have sales is smaller.

For firms demanding less automated/routine tasks at home when investing abroad, it is interesting to examine if they are instead keeping more innovation activities at home, especially given the findings in Bernard, et al. (2016). The task in $\mathrm{O}^{*}$ net that corresponds with innovation activities is the element measuring the extent and importance of thinking creatively. We find the occupations that are intensive in this job characteristic, and then we run the following regression to address this question:

$$
y_{e f}=\beta_{0}+\beta_{1} I_{\text {offshoring }_{f}}+\gamma f+C_{e} \varepsilon
$$

where $y_{e}$ is the share of employment in creativity tasks in establishment $e$ for firm $f$, $I_{\text {offshoring }_{f}}$ is an indicator of whether the cross-price elasticity of demand is positive, $f$ 
controls for firm characteristics, and $C_{e}$ accounts for establishment controls.

The creativity task measure may capture more than the innovation activities that we traditionally think are inputs in increasing productivity. We therefore also examine employment in scientific and technical occupations in equation (5).

The results are reported in Table 11. The first column presents the results when using creativity tasks to measure employment in innovation activities. The second column presents the results when using scientific and technical occupations to measure employment in innovation activities. In both regressions, we control for parent firm and industry of the establishment. Both columns show that the share of workers in innovation activities is smaller in establishments of firms that substitute domestic automated/routine tasks with foreign labor. These results suggest that the firms that are engaging in relatively high levels of exports for further processing are the ones that offshore for purely the cost-savings motive, and do not (yet) readjust domestic activities to increase future performance and productivity.

It may be then that these firms are keeping the most productive automated/routine tasks at home. To examine this question, we estimate a similar regression as the one above (equation 5), except with the dependent variable being the log weighted average wage of automated/routine tasks for each establishment. The results in Table 11 show that, after controlling for firm and industry of the establishment, wages for domestic automated/routine tasks are higher in establishments of firms that substitute these tasks for FDI.

\section{Conclusion}

We investigate the relationships between the FDI activities of multinational firms and their domestic employment and wage patterns using a unique combination of detailed survey data from BEA on the domestic and foreign operations of multinational companies with detailed domestic occupation and wage data from BLS. We find that, in general, in firms engaged in more FDI along the intensive and extensive margins, foreign labor complements 
domestic labor in every task we examine, except for automated/routine tasks. Foreign labor and automated/routine tasks are substitutes, but only for certain firms. More specifically, we find that for firms that export a significant amount to their foreign affiliates for further processing, foreign labor demand in low-income countries is negatively correlated with domestic labor demand in automated/routine tasks. However, for firms that import a significant amount of goods from their foreign affiliates, foreign labor in low-income countries complements domestic labor demand for automated/routine tasks.

In related work, we are extending the match of data from BEA and BLS surveys to follow the foreign investments and domestic employment patterns over a ten-year period, using BEA benchmark surveys from both 1999 and 2009. These expanded data will allow us to examine how changes in foreign investment patterns over time are correlated with changes in domestic employment, both in aggregate and in the domestic distributions of tasks and wages. 


\section{References}

[1] Antras, Pol and Stephen Yeaple, 2014. Multinational Firms and the Structure of International Trade. In G. Gopinath, E. Helpman, and K. Rogoff (eds), Handbook of International Economics Vol. 4. Amsterdam: Elsevier, 55-130.

[2] Autor, David, 2010. The Polarization of Job Opportunities in the U.S. Labor Market. The Hamilton Project and The Center for American Progress.

[3] Autor, David, David Dorn, and Gordon Hanson, 2013. Untangling Trade and Technology: Evidence from Labor Markets. Working Paper.

[4] Baily, M., C. Hulten, and D. Campbell, 1992. Productivity dynamics in manufacturing plants. Brookings Papers on Economic Activity, Microeconomics, 187-249.

[5] Becker, S., K. Ekholm, and M. Muendler, 2013. Offshoring and Onshore Composition of Tasks and Skills. Journal of International Economics 90(1), 91-106.

[6] Bernard, Andrew, J. Bradford Jensen, and Peter K. Schott, 2006. Survival of the Best Fit: Low Wage Competition and the (Uneven) Growth of US Manufacturing Plants. Journal of International Economics 68, 219-237.

[7] Bernard, Andrew, Valerie Smeets, and Frederic Warzynski, 2016. Rethinking deindustrialization. NBER Working Paper 22114.

[8] Blinder, Alan, 2009. How many U.S. jobs might be offshorable? World Economics $10(2), 41-78$.

[9] Brainard, S. and D. Riker, 2001. Are U.S. Multinationals Exporting U.S. Jobs? In D. Greenaway and D.R. Nelson (eds.), Globalization and Labour Markets. Northampton, MA: Edward Elgar Publishing, 410-426.

[10] Criscuolo, Chiara and Luis Garicano, 2010. Offshoring and wage inequality: Using occupational licensing as a shifter for offshoring costs. The American Economic Review 100(2), 439-443. 
[11] Davis, S. and J. Haltiwanger, 1991. Wage dispersion between and within U.S. manufacturing plants, 1963-1986. Brookings Papers on Economic Activity, Microeconomics, 115-180.

[12] Desai, M., C. Foley, and J. Hines, 2009. Foreign Direct Investment and Domestic Economic Activity, NBER Working Paper 11717.

[13] Doms, Mark and J. Bradford Jensen, 1998. Comparing Wages, Skills, and Productivity between Domestically and Foreign-Owned Manufacturing Establishments in the United States. In R. Baldwin, R. Lipsey, and J.D. Richards (eds.), Geography and Ownership as Bases for Economic Accounting. Chicago: University of Chicago Press.

[14] Ekholm, Karolina and Katariina Hakkala, 2008. The effect of offshoring on labor demand: Evidence from Sweden. Working paper.

[15] Firpo, Sergio, Nicole Fortin, and Thomas Lemieux, 2011. Occupational Tasks and Changes in the Wage Structure. Working Paper.

[16] Grossman, G. and E. Rossi-Hansberg, 2008. Trading Tasks: A Simple Theory of Offshoring. American Economic Review 98(5), 1978-1997.

[17] Hakkala, Katariina, Fredrik Heyman, and Fredrik Sjoholm, 2014. Multinational firms, acquisitions and job tasks. European Economic Review 66, 248-265.

[18] Hamermesh, Daniel, 1993. Labor Demand. Princeton, NJ: Princeton University Press.

[19] Handwerker, Elizabeth, Mina Kim, and Lowell Mason, 2011. Domestic employment in U.S.-based multinational companies. Monthly Labor Review, October.

[20] Harrison, Anne and Margaret McMillan, 2011. Offshoring jobs? Multinationals and US manufacturing employment. The Review of Economics and Statistics 93(3), 857-875.

[21] Head, Keith and John Ries, 2002. Offshore Production and Skill Upgrading by Japanese Manufacturing Firms. Journal of International Economics 58, 81-105. 
[22] Hummels, David, Jakob Munch, and Chong Xiang, 2016. Offshoring and labor markets. NBER Working Paper 22041.

[23] Jaimovich, Nir and Henry Siu, 2012. The Trend Is the Cycle: Job Polarization and Jobless Recoveries. NBER Working Paper 18334.

[24] Jensen, J. Bradford and Lori Kletzer, 2010. Measuring Tradable Services and the Task Content of Offshorable Services Jobs. In K. Abraham, M. Harper and J. Spletzer (eds.), Labor in the New Economy. Chicago: University of Chicago Press.

[25] Kovak, Brian, Lindsay Oldenski, and Nicholas Sly, 2015. The labor market effects of offshoring by US multinational firms: Evidence from changes in global tax policies. Working paper.

[26] Mataloni, Raymond, 2011. The Productivity Advantage and Global Scope of U.S. Multinational Firms. BEA Working Paper WP2011-02.

[27] Oldenski, Lindsay, 2012. Offshoring and the Polarization of the U.S. Labor Market. Working Paper.

[28] Slaughter, Matthew, 2001. International Trade and Labor-Demand Elasticities. Journal of International Economics 54, 27-56.

[29] Tomiura, Eiichi, Banri Ito, and Ryuhei Wakasugi, 2011. Offshore Outsourcing and NonProduction Workers: Firm-Level Relationships Disaggregated by Skills and Suppliers. Kier Discussion Paper No. 760. 
Table 1: Employment Totals in BEA and BLS Data

\begin{tabular}{lr}
\hline \hline BEA data from 2004 Benchmark Survey of US Direct Investment Abroad \\
Total domestic employment of companies in survey & $22,445,900$ \\
$\quad$ Employment in the companies for which the primary industry is & \\
manufacturing & $7,628,500$ \\
$\quad$ Employment in the largest 500 of these companies & $6,829,300$ \\
$\quad$ Employment in the 453 matching companies & $6,444,300$ \\
\hline BLS data from Occupational Employment Survey & $5,638,849$ \\
\hline$\quad$ Weighted employment found in establishments of these & \\
$\quad 453$ matched firms & \\
\hline & Note: \\
-Source: Handwerker, et al. (2011) & \\
-In the OES program, smaller establishments are sampled with lower probability than larger \\
establishments, and are then given larger weights in calculating estimates.
\end{tabular}

Table 2: Size and Productivity Comparison of U.S. Parents and Majority-Owned Foreign Affiliates Based on BEA Survey Data

\begin{tabular}{|c|c|c|}
\hline Averages for U.S. parents & All U.S. parents & $\begin{array}{r}\text { Matched sample } \\
\text { of manufacturing } \\
\text { U.S. parents }\end{array}$ \\
\hline Employment & 6293 & 14229 \\
\hline Compensation of employees ( $\$$ thousands) & $\$ 368,357$ & $\$ 1,029,068$ \\
\hline Value added ( $\$$ thousands) & $\$ 645,904$ & $\$ 1,876,994$ \\
\hline Labor productivity (\$VA/employment) & $\$ 99,453$ & $\$ 124,516$ \\
\hline Sales ( $\$$ thousands) & $\$ 2,097,758$ & $\$ 6,386,262$ \\
\hline $\begin{array}{l}\text { Averages for non-bank majority-owned } \\
\text { foreign affiliates (MOFAs) }\end{array}$ & $\begin{array}{r}\text { All non-bank } \\
\text { MOFAs }\end{array}$ & $\begin{array}{l}\text { Non-bank MOFAs } \\
\text { of the matched sample }\end{array}$ \\
\hline Employment & 229 & 249 \\
\hline Compensation of employees ( $\$$ thousands) & $\$ 8,757$ & $\$ 10,236$ \\
\hline Value added ( $\$$ thousands) & $\$ 21,608$ & $\$ 31,069$ \\
\hline Labor productivity (\$VA/employment) & $\$ 230,796$ & $\$ 347,883$ \\
\hline Sales (\$ thousands) & $\$ 92,328$ & $\$ 140,960$ \\
\hline
\end{tabular}


Table 3: Total Value of Goods Trade Based on BEA Survey Data (in Billions of US Dollars)

\begin{tabular}{crrrrrr}
\hline \hline & $\begin{array}{r}\text { Exports to } \\
\text { foreign } \\
\text { affiliates }\end{array}$ & $\begin{array}{r}\text { Exports to } \\
\text { foreign affiliates } \\
\text { further processing }\end{array}$ & $\begin{array}{r}\text { Exports to } \\
\text { foreign affiliates } \\
\text { for resale }\end{array}$ & $\begin{array}{r}\text { Imports from } \\
\text { Imports }\end{array}$ & $\begin{array}{r}\text { foreign } \\
\text { affiliates }\end{array}$ \\
\hline All multinationals & $\$ 413.2$ & $\$ 170.7$ & $\$ 93.8$ & $\$ 58.8$ & $\$ 497.6$ & $\$ 218.8$ \\
Manufacturing multinationals & $\$ 350.7$ & $\$ 150.7$ & $\$ 87.2$ & $\$ 48.7$ & $\$ 344.0$ & $\$ 190.0$ \\
Matching companies & $\$ 294.3$ & $\$ 129.9$ & $\$ 77.7$ & $\$ 41.6$ & $\$ 309.9$ & $\$ 175.1$ \\
\hline
\end{tabular}


Table 4: Average Task-Level Employment and Hourly Wage, across Firms and Establishments

\begin{tabular}{lrrrrrr}
\hline \hline & Automation/routinization & \multicolumn{2}{c}{ Face-to-face } & \multicolumn{2}{c}{ Information content } \\
\hline & $\begin{array}{r}\text { Average } \\
\text { employment }\end{array}$ & $\begin{array}{r}\text { Average } \\
\text { wWage }\end{array}$ & $\begin{array}{r}\text { Average } \\
\text { employment }\end{array}$ & $\begin{array}{r}\text { Average } \\
\text { wage }\end{array}$ & $\begin{array}{r}\text { Average } \\
\text { employment }\end{array}$ & $\begin{array}{r}\text { Average } \\
\text { wage }\end{array}$ \\
\hline Firm & & & & & & \\
Mean & $2,093.22$ & $\$ 16.77$ & 260.04 & $\$ 18.81$ & 983.53 & $\$ 19.53$ \\
Standard deviation & $2,893.48$ & $\$ 3.15$ & 740.27 & $\$ 7.93$ & $1,759.32$ & $\$ 4.36$ \\
N & 414 & & & & & \\
\hline Establishment & & & & & & \\
Mean & 34.47 & $\$ 11.85$ & 4.28 & $\$ 4.50$ & 16.19 & $\$ 11.33$ \\
Standard Deviation & 98.29 & $\$ 9.24$ & 22.97 & $\$ 9.67$ & 64.55 & $\$ 11.91$ \\
N & 25144 & & & & & \\
\hline
\end{tabular}


Table 5: Descriptive Statistics for Global Engagement Variables

\begin{tabular}{lrrr}
\hline \hline & Mean & $\begin{array}{r}\text { Standard } \\
\text { deviation }\end{array}$ & $\mathrm{N}$ \\
\hline Variable & $\$ 25,054$ & $\$ 26,784$ & 414 \\
$\quad \begin{array}{l}\text { Global scope, } \$ \\
\quad \text { to foreign affiliates, } \$ \text { thousands }\end{array}$ & $\$ 199,510$ & $\$ 953,039$ & 404 \\
$\quad \begin{array}{l}\text { Exports for resale } \\
\quad \text { to foreign affiliates, } \$ \text { thousands }\end{array}$ & $\$ 107,109$ & $\$ 385,741$ & 404 \\
$\begin{array}{l}\text { Other exports } \\
\quad \text { to foreign affiliates, } \$ \text { thousands }\end{array}$ & $\$ 8,164$ & $\$ 71,729$ & 404 \\
Imports from foreign affiliates, $\$$ thousands & $\$ 432,670$ & $\$ 2,397,321$ & 404 \\
\hline
\end{tabular}


Table 6: Labor Demand Regression Results - Global Scope

\begin{tabular}{|c|c|c|c|c|}
\hline & $\begin{array}{c}\text { Automation/ } \\
\text { routinization } \\
\text { tasks } \\
\end{array}$ & $\begin{array}{c}\text { Information } \\
\text { content-related } \\
\text { tasks }\end{array}$ & $\begin{array}{c}\text { Face-to-face } \\
\text { interaction } \\
\text { tasks } \\
\end{array}$ & Other tasks \\
\hline \multirow[t]{2}{*}{ Intercept } & 8.74 & 3.75 & 2.13 & 5.99 \\
\hline & $(0.82) * * *$ & $(0.73) * * *$ & $(1.64)$ & $(0.50) * * *$ \\
\hline \multirow[t]{2}{*}{ Log domestic wage for task $\mathrm{X}$} & -1.65 & -0.89 & -2.09 & -0.51 \\
\hline & $(0.39) * * *$ & $(0.26) * * *$ & $(0.33) * * *$ & $(0.18) * * *$ \\
\hline \multirow[t]{2}{*}{ Log domestic wage for other tasks } & 0.86 & 1.28 & 2.76 & 1.08 \\
\hline & $(0.33) * * *$ & $(0.26) * * *$ & $(0.72) * * *$ & $(0.22) * * *$ \\
\hline \multirow[t]{2}{*}{ Log affiliate wage } & 0.08 & -0.01 & -0.17 & -0.05 \\
\hline & $(0.04) * *$ & $(0.04)$ & $(0.09) *$ & $(0.02) * *$ \\
\hline \multirow[t]{2}{*}{ Global scope*Log affiliate wage } & -0.15 & -0.13 & -0.19 & -0.14 \\
\hline & $(0.02) * * *$ & $(0.02) * * *$ & $(0.05) * * *$ & $(0.01) * * *$ \\
\hline \multirow[t]{2}{*}{ Log domestic sales } & 0.06 & 0.07 & -0.05 & 0.06 \\
\hline & $(0.06)$ & $(0.06)$ & $(0.15)$ & $(0.04)$ \\
\hline \multirow[t]{2}{*}{ Log foreign sales } & -0.11 & -0.04 & 0.06 & 0.00 \\
\hline & $(0.05) * *$ & $(0.04)$ & $(0.11)$ & $(0.03)$ \\
\hline \multirow[t]{2}{*}{ Log domestic price of capital } & -0.50 & -1.02 & 1.04 & 1.02 \\
\hline & $(0.72)$ & $(0.68) * * *$ & $(1.65)$ & $(0.45) * *$ \\
\hline \multirow[t]{2}{*}{ Log price of foreign capital } & -0.01 & -0.02 & 0.55 & -0.11 \\
\hline & $(0.18)$ & $(0.18)$ & $(0.42)$ & $(0.11)$ \\
\hline Domestic expenditure on R\&D & -2.06 & 0.04 & 0.60 & 1.16 \\
\hline as percent of sales & $(0.56) * * *$ & $(0.53)$ & $(1.28)$ & $(0.35) * * *$ \\
\hline Affiliate expenditure on $R \& D$ & -0.99 & -1.08 & -2.71 & -1.33 \\
\hline as percent of sales & $(0.70)$ & $(0.67)$ & $(1.63) *$ & $(0.43) * * *$ \\
\hline \multirow[t]{2}{*}{ Import penetration } & -0.74 & 0.16 & 0.86 & 0.12 \\
\hline & $(0.21) * * *$ & $(0.21) * *$ & $(0.49) *$ & $(0.13)$ \\
\hline Controls for worldwide size of firm & $\mathrm{x}$ & $\mathrm{x}$ & $\mathrm{x}$ & $\mathrm{x}$ \\
\hline Controls for age of firm & $\mathrm{x}$ & $\mathrm{x}$ & $\mathrm{x}$ & $\mathrm{x}$ \\
\hline $\mathrm{N}$ & 386 & 386 & 386 & 386 \\
\hline$R^{2}$ & 0.684 & 0.684 & 0.684 & 0.684 \\
\hline
\end{tabular}


Table 7: Labor Demand Regression Results for Tradeable Tasks by Location of FDI Intrafirm Goods Trade

\begin{tabular}{|c|c|c|c|c|}
\hline & \multicolumn{2}{|c|}{$\begin{array}{c}\text { Automation/ } \\
\text { routinization tasks }\end{array}$} & \multicolumn{2}{|c|}{$\begin{array}{l}\text { Information content- } \\
\text { related tasks }\end{array}$} \\
\hline & (1a) & $(1 b)$ & $(2 \mathrm{a})$ & $(2 \mathrm{~b})$ \\
\hline Intercept & $\begin{array}{l}8.17 \\
(1.03) * * *\end{array}$ & $\begin{array}{l}7.73 \\
(1.04) * * *\end{array}$ & $\begin{array}{l}3.89 \\
(0.94) * * *\end{array}$ & $\begin{array}{l}3.52 \\
(0.95) * * *\end{array}$ \\
\hline Log domestic wage for task $\mathrm{X}$ & $\begin{array}{l}-1.26 \\
(0.42) * * *\end{array}$ & $\begin{array}{l}-1.09 \\
(0.42) * * *\end{array}$ & $\begin{array}{l}-0.87 \\
(0.28) * * *\end{array}$ & $\begin{array}{l}-0.75 \\
(0.28) * * *\end{array}$ \\
\hline Log domestic wage for other tasks & $\begin{array}{l}0.67 \\
(0.34) * *\end{array}$ & $\begin{array}{c}0.65 \\
(0.34) *\end{array}$ & $\begin{array}{l}1.26 \\
(0.28) * * *\end{array}$ & $\begin{array}{l}1.26 \\
(0.28) * * *\end{array}$ \\
\hline $\begin{array}{l}\text { Log affiliate wage } \\
\text { in high-income countries }\end{array}$ & $\begin{array}{l}0.12 \\
(0.04) * * *\end{array}$ & $\begin{array}{l}0.12 \\
(0.04) * * *\end{array}$ & $\begin{array}{c}-0.04 \\
(0.04)\end{array}$ & $\begin{array}{c}-0.02 \\
(0.04)\end{array}$ \\
\hline $\begin{array}{l}\text { Log affiliate wage } \\
\text { in low-income countries }\end{array}$ & $\begin{array}{c}-0.04 \\
(0.06)\end{array}$ & $\begin{array}{l}-0.03 \\
(0.06)\end{array}$ & $\begin{array}{c}0.03 \\
(0.06)\end{array}$ & $\begin{array}{c}0.02 \\
(0.06)\end{array}$ \\
\hline $\begin{array}{l}\text { Exports to affiliates } \\
\text { for further processing } \\
\text { as percent of sales } \\
\text { * Log high-income wage }\end{array}$ & $\begin{array}{r}-0.75 \\
(0.64)\end{array}$ & $\begin{array}{c}-0.21 \\
(0.34)\end{array}$ & $\begin{array}{c}0.62 \\
(0.63)\end{array}$ & $\begin{array}{c}0.26 \\
(0.33)\end{array}$ \\
\hline $\begin{array}{l}\text { Exports to affiliates } \\
\text { for resale }\end{array}$ & & & & \\
\hline $\begin{array}{l}\text { as percent of sales } \\
\text { * Log high-income wage }\end{array}$ & $\begin{array}{l}-1.10 \\
(0.45) * *\end{array}$ & $\begin{array}{l}-1.36 \\
(0.51) * * *\end{array}$ & $\begin{array}{r}-0.24 \\
(0.44)\end{array}$ & $\begin{array}{l}-1.06 \\
(0.50) * *\end{array}$ \\
\hline Imports from affiliates & & & & \\
\hline $\begin{array}{l}\text { as percent of sales } \\
* \text { Log high-income wage }\end{array}$ & $\begin{array}{l}-0.63 \\
(0.25) * *\end{array}$ & $\begin{array}{l}-0.50 \\
(0.23) * *\end{array}$ & $\begin{array}{l}-0.41 \\
(0.25) *\end{array}$ & $\begin{array}{l}-0.57 \\
(0.23) * *\end{array}$ \\
\hline $\begin{array}{l}\text { Exports to affiliates } \\
\text { for further processing } \\
\text { as percent of sales } \\
\text { * Log low-income wage }\end{array}$ & $\begin{array}{l}6.34 \\
(2.43) * * *\end{array}$ & $\begin{array}{l}-2.58 \\
(44.62)\end{array}$ & $\begin{array}{l}1.73 \\
(2.38)\end{array}$ & $\begin{array}{c}0.73 \\
(43.44)\end{array}$ \\
\hline $\begin{array}{l}\text { Exports to affiliates } \\
\text { for resale }\end{array}$ & & & & \\
\hline $\begin{array}{l}\text { as percent of sales } \\
\text { * Log low-income wage }\end{array}$ & $\begin{array}{l}-5.98 \\
(5.11)\end{array}$ & $\begin{array}{c}746.29 \\
(725.23)\end{array}$ & $\begin{array}{l}-10.90 \\
\quad(5.05) * *\end{array}$ & $\begin{array}{c}586.06 \\
(706.16)\end{array}$ \\
\hline $\begin{array}{l}\text { Imports from affiliates } \\
\text { as percent of sales } \\
\quad * \text { Log low-income wage }\end{array}$ & $\begin{array}{l}-6.62 \\
(2.55) * * *\end{array}$ & $\begin{array}{c}12.79 \\
(79.69)\end{array}$ & $\begin{array}{l}-4.82 \\
(2.51) *\end{array}$ & $\begin{array}{l}-0.84 \\
(77.60)\end{array}$ \\
\hline Log domestic sales & $\begin{array}{l}0.14 \\
(0.07) * *\end{array}$ & $\begin{array}{l}0.14 \\
(0.07) * *\end{array}$ & $\begin{array}{l}0.16 \\
(0.06) * *\end{array}$ & $\begin{array}{l}0.16 \\
(0.06) * *\end{array}$ \\
\hline Log foreign sales & $\begin{array}{l}-0.18 \\
(0.05) * * *\end{array}$ & $\begin{array}{l}-0.18 \\
(0.05) * * *\end{array}$ & $\begin{array}{l}-0.13 \\
(0.04) * * *\end{array}$ & $\begin{array}{l}-0.14 \\
(0.04) * * *\end{array}$ \\
\hline
\end{tabular}


Table 7 - Continued from previous page

\begin{tabular}{lcccc}
\hline & \multicolumn{2}{c}{$\begin{array}{c}\text { Automation/ } \\
\text { routinization tasks } \\
\end{array}$} & \multicolumn{2}{c}{$\begin{array}{c}\text { Information content- } \\
\text { related tasks }\end{array}$} \\
& -0.11 & -0.01 & -0.71 & -0.69 \\
\hline Log domestic price of capital & $(0.79)$ & $(0.81)$ & $(0.77)$ & $(0.78)$ \\
& 0.51 & 0.51 & 0.22 & 0.20 \\
Log price of foreign capital & $(0.18) * * *$ & $(0.18) * * *$ & $(0.18)$ & $(0.18)$ \\
& -1.56 & -1.23 & 0.60 & 0.42 \\
Domestic expenditure on R\&D & $(0.59) * * *$ & $(0.57) * *$ & $(0.56)$ & $(0.54)$ \\
$\quad$ as percent of sales & & & & \\
Affiliate expenditure on R\&D & -0.77 & -1.22 & -1.38 & -1.26 \\
$\quad$ as percent of sales & $(0.72)$ & $(0.70) *$ & $(0.70) *$ & $(0.68) *$ \\
$\quad$ in high-income countries & & & & \\
Affiliate expenditure on R\&D & 5.21 & 5.03 & 3.97 & 4.04 \\
$\quad$ as percent of sales & $(3.53)$ & $(3.58)$ & $(3.46)$ & $(3.48)$ \\
$\quad$ in low-income countries & -0.10 & 0.04 & 0.44 & 0.47 \\
No investment & $(0.51)$ & $(0.53)$ & $(0.51)$ & $(0.52)$ \\
$\quad$ in low-income countries & -0.87 & -1.01 & 0.35 & 0.29 \\
Import penetration & $(0.25) * * *$ & $(0.25) * * *$ & $(0.25)$ & $(0.25)$ \\
& 6.59 & 7.31 & -2.73 & -2.23 \\
Import penetration & $(2.83) * *$ & $(2.88) * *$ & $(2.72)$ & $(2.73)$ \\
$\quad$ from low-income countries & $\mathrm{x}$ & $\mathrm{x}$ & $\mathrm{x}$ & $\mathrm{x}$ \\
\hline Controls for worldwide size of firm & $\mathrm{x}$ & $\mathrm{x}$ & $\mathrm{x}$ & $\mathrm{x}$ \\
Controls for age of firm & 373 & 373 & 373 & 373 \\
$\mathrm{~N}$ & 0.641 & 0.640 & 0.641 & 0.640 \\
$R^{2}$ & & & & \\
\hline
\end{tabular}

Note:

-Dependent Variable is domestic log employment in task X.

-In columns labeled (b), intrafirm trade is disaggregated across high- and low-income locations.

- ${ }^{*}$ significant at the $10 \%$ level, ${ }^{* *}$ significant at the $5 \%$ level, ${ }^{* * *}$ significant at the $1 \%$ level

-The $R^{2}$ is a system-weighted number produced by the proc syslin procedure in SAS. 
Table 8: Labor Demand Regression Results for Non-Tradeable Tasks by Location of FDI Intrafirm Goods Trade

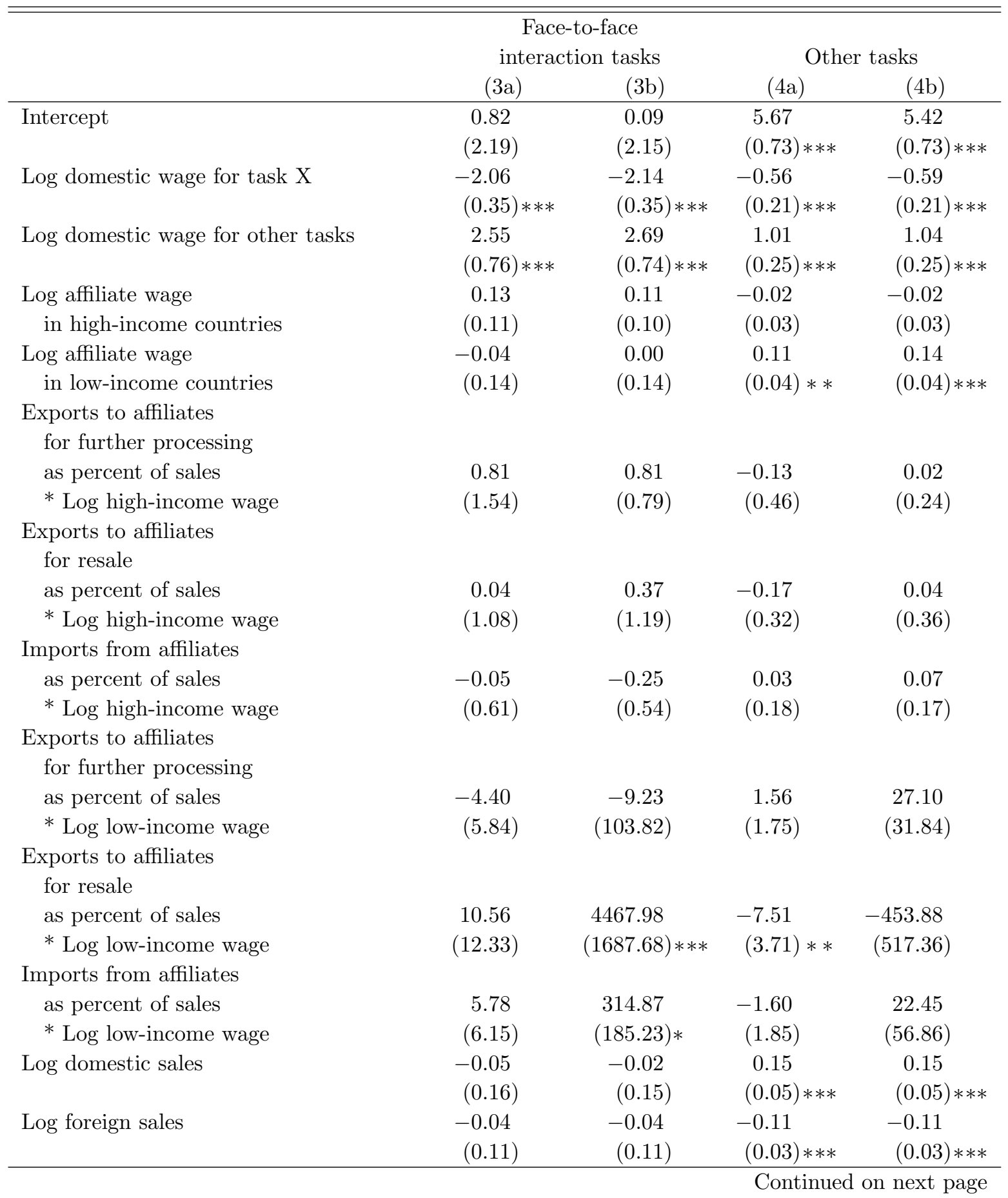


Table 8 - Continued from previous page

\begin{tabular}{|c|c|c|c|c|}
\hline & \multicolumn{2}{|c|}{ Face-to-face } & \multicolumn{2}{|c|}{ Other tasks } \\
\hline & $(3 \mathrm{a})$ & $(3 b)$ & $(4 a)$ & $(4 \mathrm{~b})$ \\
\hline \multirow[t]{2}{*}{ Log domestic price of capital } & -0.10 & -0.16 & 0.50 & 0.22 \\
\hline & $(1.88)$ & $(1.87) * *$ & $(0.58)$ & $(0.58) * * *$ \\
\hline \multirow[t]{2}{*}{ Log price of foreign capital } & 0.68 & 0.85 & 0.18 & 0.18 \\
\hline & $(0.43)$ & $(0.42)$ & $(0.13)$ & $(0.13) * * *$ \\
\hline \multirow{2}{*}{$\begin{array}{l}\text { Domestic expenditure on R\&D } \\
\text { as percent of sales }\end{array}$} & 1.23 & 1.18 & 1.25 & 1.21 \\
\hline & $(1.38)$ & $(1.29) *$ & $(0.42) * * *$ & $(0.40) * * *$ \\
\hline \multicolumn{5}{|l|}{ Affiliate expenditure on R\&D } \\
\hline as percent of sales & -3.11 & -3.02 & -1.13 & -1.05 \\
\hline \multirow{2}{*}{\multicolumn{5}{|c|}{ Affiliate expenditure on R\&D }} \\
\hline & & & & \\
\hline as percent of sales & 5.56 & 4.76 & 2.70 & 2.66 \\
\hline in low-income countries & $(8.50)$ & $(8.31)$ & $(2.55)$ & $(2.55)$ \\
\hline \multirow{2}{*}{$\begin{array}{l}\text { No investment } \\
\text { in low-income countries }\end{array}$} & 0.25 & 0.69 & 1.06 & 1.33 \\
\hline & $(1.25)$ & $(1.24)$ & $(0.38) * * *$ & $(0.38) * * *$ \\
\hline \multirow[t]{2}{*}{ Import penetration } & 0.64 & 0.55 & 0.21 & 0.11 \\
\hline & $(0.59)$ & $(0.57)$ & $(0.17)$ & $(0.17)$ \\
\hline \multirow{2}{*}{$\begin{array}{l}\text { Import penetration } \\
\text { from low-income countries }\end{array}$} & 5.61 & 6.76 & -3.45 & -2.73 \\
\hline & $(6.74)$ & $(6.58)$ & $(1.96) *$ & $(1.96)$ \\
\hline Controls for worldwide size of firm & $\mathrm{x}$ & $\mathrm{x}$ & $\mathrm{x}$ & $\mathrm{x}$ \\
\hline Controls for age of firm & $\mathrm{x}$ & $\mathrm{x}$ & $\mathrm{x}$ & $\mathrm{x}$ \\
\hline $\mathrm{N}$ & 373 & 373 & 373 & 373 \\
\hline$R^{2}$ & 0.641 & 0.640 & 0.641 & 0.640 \\
\hline
\end{tabular}

Note:

-Dependent Variable is domestic log employment in task X.

-In columns labeled (b), intrafirm trade is disaggregated across high- and low-income locations.

- * significant at the $10 \%$ level, ${ }^{* *}$ significant at the $5 \%$ level, ${ }^{* * *}$ significant at the $1 \%$ level

-The $R^{2}$ is a system-weighted number produced by the proc syslin procedure in SAS. 
Table 9: Labor Demand Regression Results by Location of FDI - Intrafirm Goods Trade (from averages of 1999 and 2004 Benchmark Surveys)

\begin{tabular}{|c|c|c|c|c|}
\hline & $\begin{array}{c}\text { Automation/ } \\
\text { routinization } \\
\text { tasks }\end{array}$ & $\begin{array}{c}\text { Information } \\
\text { content-related } \\
\text { tasks }\end{array}$ & $\begin{array}{l}\text { Face-to-face } \\
\text { interaction } \\
\text { tasks }\end{array}$ & Other tasks \\
\hline Intercept & $\begin{array}{l}7.75 \\
(1.08) * * *\end{array}$ & $\begin{array}{l}4.38 \\
(0.98) * * *\end{array}$ & $\begin{array}{c}0.54 \\
(2.29)\end{array}$ & $\begin{array}{l}5.46 \\
(0.77) * * *\end{array}$ \\
\hline Log domestic wage for task $\mathrm{X}$ & $\begin{array}{l}-1.18 \\
(0.43) * * *\end{array}$ & $\begin{array}{l}-0.91 \\
(0.29) * * *\end{array}$ & $\begin{array}{l}-2.31 \\
(0.36) * * *\end{array}$ & $\begin{array}{l}-0.50 \\
(0.22) * *\end{array}$ \\
\hline Log domestic wage for other tasks & $\begin{array}{l}0.62 \\
(0.36) *\end{array}$ & $\begin{array}{l}1.17 \\
(0.30) * * *\end{array}$ & $\begin{array}{l}2.93 \\
(0.78) * * *\end{array}$ & $\begin{array}{l}0.99 \\
(0.26) * * *\end{array}$ \\
\hline $\begin{array}{l}\text { Log affiliate wage } \\
\text { in high-income countries }\end{array}$ & $\begin{array}{l}0.16 \\
(0.05) * * *\end{array}$ & $\begin{array}{c}-0.03 \\
(0.04)\end{array}$ & $\begin{array}{l}0.07 \\
(0.11)\end{array}$ & $\begin{array}{c}-0.01 \\
(0.03)\end{array}$ \\
\hline $\begin{array}{l}\text { Log affiliate wage } \\
\text { in low-income countries }\end{array}$ & $\begin{array}{c}-0.03 \\
(0.06)\end{array}$ & $\begin{array}{c}0.04 \\
(0.05)\end{array}$ & $\begin{array}{c}-0.02 \\
(0.14)\end{array}$ & $\begin{array}{l}0.11 \\
(0.04) * *\end{array}$ \\
\hline $\begin{array}{l}\text { Exports to affiliates } \\
\text { for further processing } \\
\text { as percent of sales } \\
{ }^{*} \text { Log high-income wage }\end{array}$ & $\begin{array}{l}-1.20 \\
(0.71) *\end{array}$ & $\begin{array}{l}1.05 \\
(0.70)\end{array}$ & $\begin{array}{c}2.04 \\
(1.72)\end{array}$ & $\begin{array}{c}-0.46 \\
(0.53)\end{array}$ \\
\hline $\begin{array}{l}\text { Exports to affiliates } \\
\text { for resale } \\
\text { as percent of sales } \\
\text { * Log high-income wage }\end{array}$ & $\begin{array}{c}-0.81 \\
(0.61)\end{array}$ & $\begin{array}{c}-0.30 \\
(0.60)\end{array}$ & $\begin{array}{c}1.25 \\
(1.47)\end{array}$ & $\begin{array}{c}0.07 \\
(0.45)\end{array}$ \\
\hline $\begin{array}{l}\text { Imports from affiliates } \\
\text { as percent of sales } \\
* \text { Log high-income wage }\end{array}$ & $\begin{array}{l}-0.33 \\
(0.11) * * *\end{array}$ & $\begin{array}{c}-0.15 \\
(0.11)\end{array}$ & $\begin{array}{c}-0.49 \\
(0.27) *\end{array}$ & $\begin{array}{c}-0.12 \\
(0.08)\end{array}$ \\
\hline $\begin{array}{l}\text { Exports to affiliates } \\
\text { for further processing } \\
\text { as percent of sales } \\
{ }^{*} \text { Log low-income wage }\end{array}$ & $\begin{array}{l}5.16 \\
(2.09) * *\end{array}$ & $\begin{array}{c}3.18 \\
(2.06)\end{array}$ & $\begin{array}{c}-6.97 \\
(4.99)\end{array}$ & $\begin{array}{c}1.14 \\
(1.55)\end{array}$ \\
\hline $\begin{array}{l}\text { Exports to affiliates } \\
\text { for resale }\end{array}$ & & & & \\
\hline $\begin{array}{l}\text { as percent of sales } \\
* \text { Log low-income wage }\end{array}$ & $\begin{array}{c}-1.31 \\
(2.90)\end{array}$ & $\begin{array}{l}-6.37 \\
(2.87) * *\end{array}$ & $\begin{array}{c}2.52 \\
(6.91)\end{array}$ & $\begin{array}{l}-3.90 \\
(2.14) *\end{array}$ \\
\hline $\begin{array}{l}\text { Imports from affiliates } \\
\text { as percent of sales } \\
\quad * \text { Log low-income wage }\end{array}$ & $\begin{array}{l}-3.28 \\
(1.74) *\end{array}$ & $\begin{array}{l}-4.22 \\
(1.72) * *\end{array}$ & $\begin{array}{c}5.48 \\
(4.17)\end{array}$ & $\begin{array}{c}0.31 \\
(1.29)\end{array}$ \\
\hline Log domestic sales & $\begin{array}{l}0.14 \\
(0.07) * *\end{array}$ & $\begin{array}{l}0.16 \\
(0.07) * *\end{array}$ & $\begin{array}{c}-0.11 \\
(0.16)\end{array}$ & $\begin{array}{l}0.14 \\
(0.05) * * *\end{array}$ \\
\hline Log foreign sales & $\begin{array}{l}-0.21 \\
(0.05) * * *\end{array}$ & $\begin{array}{l}-0.15 \\
(0.05) * * *\end{array}$ & $\begin{array}{c}-0.01 \\
(0.11)\end{array}$ & $\begin{array}{l}-0.12 \\
(0.03) * * * *\end{array}$ \\
\hline
\end{tabular}


Table 9 - Continued from previous page

\begin{tabular}{lcccc}
\hline & $\begin{array}{c}\text { Automation/ } \\
\text { routinization } \\
\text { tasks }\end{array}$ & $\begin{array}{c}\text { Information } \\
\text { content-related } \\
\text { tasks }\end{array}$ & $\begin{array}{c}\text { Face-to-face } \\
\text { interaction } \\
\text { tasks }\end{array}$ & Other tasks \\
\hline Log domestic price of capital & -0.83 & -1.38 & 0.35 & 0.44 \\
& $(0.82)$ & $(0.79) *$ & $(1.93)$ & $(0.61)$ \\
Log price of foreign capital & 0.38 & 0.18 & 0.68 & 0.18 \\
& $(0.20) *$ & $(0.20)$ & $(0.48)$ & $(0.15)$ \\
Domestic expenditure on R\&D & -1.84 & 0.31 & 0.84 & 1.09 \\
$\quad$ as percent of sales & $(0.66) * * *$ & $(0.62)$ & $(1.51)$ & $(0.48) * *$ \\
Affiliate expenditure on R\&D & & & & \\
$\quad$ as percent of sales & -0.80 & -1.20 & -3.13 & -1.07 \\
in high-income countries & $(0.75)$ & $(0.74)$ & $(1.78) *$ & $(0.55) *$ \\
Affiliate expenditure on R\&D & & & & \\
$\quad$ as percent of sales & 4.59 & 3.46 & 4.99 & 2.40 \\
$\quad$ in low-income countries & $(3.49)$ & $(3.43)$ & $(8.32)$ & $(2.57)$ \\
No investment & 0.04 & 0.49 & 0.38 & 1.07 \\
$\quad$ in low-income countries & $(0.52)$ & $(0.52)$ & $(1.26)$ & $(0.39) * * *$ \\
Import penetration & -0.86 & 0.47 & 1.06 & 0.23 \\
& $(0.26) * * *$ & $(0.26) *$ & $(0.61) *$ & $(0.18)$ \\
Import penetration & 6.31 & -2.98 & -9.46 & -6.05 \\
$\quad$ from low-income countries & $(3.23) *$ & $(3.10)$ & $(7.61)$ & $(2.86) * * *$ \\
\hline Controls for worldwide size of firm & $\mathrm{x}$ & $\mathrm{x}$ & $\mathrm{x}$ & $\mathrm{x}$ \\
Controls for age of firm & $\mathrm{x}$ & $\mathrm{x}$ & $\mathrm{x}$ & $\mathrm{x}$ \\
$\mathrm{N}$ ( & 337 & 337 & 337 & 337 \\
$R^{2}$ & 0.652 & 0.652 & 0.652 & 0.652 \\
\hline
\end{tabular}

Note:

-Dependent Variable is domestic log employment in task X.

-In columns labeled (b), intrafirm trade is disaggregated across high- and low-income locations.

- * significant at the $10 \%$ level, ${ }^{* *}$ significant at the $5 \%$ level, ${ }^{* * *}$ significant at the $1 \%$ level

-The $R^{2}$ is a system-weighted number produced by the proc syslin procedure in SAS. 
Table 10: Comparison of Firms That Substitute Domestic Automated/Routine Tasks for Foreign Labor in Low-Income Countries vs. Firms That Do Not

\begin{tabular}{|c|c|c|c|c|c|}
\hline & Age & Size & $\begin{array}{l}\text { Ratio of FDI } \\
\text { in low- to high- } \\
\text { income countries }\end{array}$ & $\begin{array}{r}\text { Share of foreign } \\
\text { affiliate employment } \\
\text { in different 3-Digit NAICS }\end{array}$ & $\begin{array}{r}\text { Number of } \\
\text { parent industries }\end{array}$ \\
\hline \multicolumn{6}{|c|}{ Firms with positive cross-price elasticity of demand } \\
\hline Mean & 20.0 & 8958 & 0.01 & 0.07 & 2.31 \\
\hline Std Dev & 20.1 & 8246 & 0.02 & 0.15 & 1.82 \\
\hline \multicolumn{6}{|c|}{ Firms with negative cross-price elasticity of demand } \\
\hline Mean & 38.6 & 28355 & 0.20 & 0.35 & 4.00 \\
\hline Std Dev & 30.8 & 56417 & 3.00 & 0.37 & 3.24 \\
\hline \multicolumn{6}{|c|}{$\begin{array}{l}\text { Note: } \\
\text {-Age is proxied by the number of years that a U.S. parent company is included in the BEA surveys. } \\
\text {-Size is determined by the number of employees worldwide. } \\
\text {-The ratio of FDI in low- to high-income countries is determined by the share of employment in foreign } \\
\text { affiliates that are in low- vs. high-income countries. } \\
\text {-The number of parent industries is the number of industries in which the U.S. parent has sales (up } \\
\text { to 10). }\end{array}$} \\
\hline
\end{tabular}

Table 11: Difference in Employment Shares Between Firms That Substitute Domestic Automated/Routine Tasks for FDI and Firms That Do Not, by Establishment

\begin{tabular}{lrr}
\hline \hline Automation/routinization & $\begin{array}{r}\text { Science and } \\
\text { technology } \\
\text { occupations }\end{array}$ \\
\hline Indicator for firms that substitute & -0.058 & -0.055 \\
Control for parent firm & $(0.031)^{*}$ & $(0.032)^{*}$ \\
Control for establishment industry & $\mathrm{x}$ & $\mathrm{x}$ \\
$\mathrm{N}$ & $\mathrm{x}$ & $\mathrm{x}$ \\
$R^{2}$ & 24847 & 24847 \\
\hline
\end{tabular}

Note:

-Dependent Variable is the share of domestic workers in occupations that require innovation.

- * significant at the $10 \%$ level, ** significant at the $5 \%$ level, *** significant at the $1 \%$ level 
Table 12: Difference in Wages for Domestic Automated/Routine Tasks Between Firms That Substitute These Tasks for FDI and Firms That Do Not, by Establishment

\begin{tabular}{lr}
\hline \hline & $\begin{array}{r}\text { Automation/ } \\
\text { routinization }\end{array}$ \\
Indicator for firms that substitute & 2.07 \\
& $(1.07)^{*}$ \\
Control for parent firm & $\mathrm{x}$ \\
Control for establishment industry & $\mathrm{x}$ \\
$\mathrm{N}$ & 17181 \\
$R^{2}$ & 0.354 \\
\hline Note: & \\
- Dependent Variable is the log wage of domestic work- \\
ers in automated/routine tasks. \\
$-{ }^{*}$ significant at the $10 \%$ level, ** significant at the \\
$5 \%$ level, *** significant at the 1\% level
\end{tabular}




\section{Appendices}

\section{A Technical Notes about the OES Data}

\section{A.1 Sample design, Missing Matches, and Weights}

Establishments for a given firm may be missing from our sample, and missing in a nonrandom fashion, due to imperfect matching between the firm and the establishments or due to the sample design. Handwerker, et al. (2011) noted that they had difficulty finding the very small establishments of these firms, such as their sales offices. Additionally, the sampling design of the OES survey was designed to produce estimates at the industry/state level. Therefore, small establishments are sampled with smaller probability than large establishments, which are sampled with certainty over the three-year sample design. Again small establishments are more likely to be missing from our estimates, and could bias the estimates of a firm's occupational distribution.

We rely on weights to account for these missing establishments. In particular we use the benchmark weights, which are designed to account for sampling probabilities, such that the data represent the current universe of establishments at the industry/state level. These weights potentially could bias our employment estimates if, for example, multinational employment behavior is different than that of non-multinationals. Although these weights were not specifically designed for our study, weighted data only comprise of $7 \%$ of employment in our sample. Table 1 shows the share of weighted data across all tasks.

Table 1: Share of Weighted Data in Total Employment of the Matched U.S. Multinationals, by Task

\begin{tabular}{lcccc}
\hline \hline & & Information & & \\
& $\begin{array}{c}\text { Automation/ } \\
\text { Routinization }\end{array}$ & $\begin{array}{c}\text { Content- } \\
\text { Related }\end{array}$ & $\begin{array}{c}\text { Face-to-Face } \\
\text { Interactions }\end{array}$ & Other \\
\hline Share of weighted data & $3.8 \%$ & $6.4 \%$ & $44.2 \%$ & $7.2 \%$ \\
\hline
\end{tabular}

\section{A.2 Non-respondents}

About $30 \%$ of the establishments on average do not respond in the OES survey. For each nonrespondent, the occupational distribution of the establishment is imputed using nearestneighbor "hot-deck" imputation method. A responding establishments are linked to a nonrespondent based on geographic area, industry, and employment size with the current panel of any of the previous five panels. A donor from the most recent panel is then used to prorate the non-respondent's occupational distribution.

Excluding the non-respondents is not possible, as these non-respondents are not random. Table 2 shows the distribution of imputed data across the industry of the establishments, while Table 3 shows the distribution of imputed data across size classes, by which the OES 
program disaggregates the data. These tables show that the imputed data are concentrated in the larger establishments and are not evenly spread across two-digit NAICS industries.

Table 2: Share Imputed Data in Total Employment of the Matched U.S. Multinationals, by Industry of Establishment

\begin{tabular}{rlr}
\hline \hline & & $\begin{array}{r}\text { Share of } \\
\text { NAICS Sector }\end{array}$ \\
\hline 11 & Agriculture, Forestry, Fishing, and Hunting & $9.8 \%$ \\
21 & Mining & $46.4 \%$ \\
22 & Utilities & $42.6 \%$ \\
23 & Construction & $38.7 \%$ \\
$31-33$ & Manufacturing & $38.8 \%$ \\
42 & Wholesale Trade & $40.8 \%$ \\
$44-45$ & Retail Trade & $20.5 \%$ \\
$48-49$ & Transportation and Warehousing & $31.3 \%$ \\
51 & Information & $53.3 \%$ \\
52 & Finance and Insurance & $59.6 \%$ \\
53 & Real Estate and Rental and Leasing & $27.3 \%$ \\
54 & Professional, Scientific, and Technical Services & $42.7 \%$ \\
55 & Management of Companies and Enterprises & $56.4 \%$ \\
56 & Administrative Support; Waste Management and Remediation Services & $43.7 \%$ \\
61 & Educational Services & $55.6 \%$ \\
62 & Health Care and Social Assistance & $34.2 \%$ \\
71 & Arts, Entertainment, and Recreation & $19.9 \%$ \\
72 & Other Services (Except Public Administration) & $18.5 \%$ \\
81 & Public Administration & $29.9 \%$ \\
\hline
\end{tabular}

Table 3: Share of Imputed Data in Total Employment of the Matched U.S. Multinationals, by Size of Establishment

\begin{tabular}{lr}
\hline \hline Size & $\begin{array}{r}\text { Share of } \\
\text { Imputed Data }\end{array}$ \\
\hline Less than 5 Employees & $2.1 \%$ \\
5 to 9 Employees & $4.1 \%$ \\
10 to 19 Employees & $8.9 \%$ \\
20 to 49 Employees & $20.4 \%$ \\
50 to 99 Employees & $35.0 \%$ \\
100 to 249 Employees & $39.0 \%$ \\
250 or More Employees & $44.9 \%$ \\
\hline
\end{tabular}




\section{B Distribution of Firms by Industry and Location}

In the following tables, we compare the matched multinationals to the universe of multinationals.

Table 4: Distribution of U.S. Parent Firms, by 3-digit NAICS

\begin{tabular}{|c|c|c|c|c|c|c|}
\hline \multirow[b]{2}{*}{ 3-Digit NAICS Sub-sector } & \multicolumn{6}{|c|}{ All Multinational Manufacturers } \\
\hline & $\begin{array}{l}\text { Employment } \\
\text { (Thousands) }\end{array}$ & $\begin{array}{r}\text { Value } \\
\text { Added } \\
(\$ \text { Millions }) \\
\end{array}$ & $\begin{array}{r}\text { Sales } \\
(\$ \text { Millions }) \\
\end{array}$ & $\begin{array}{r}\text { Share of } \\
\text { Manufacturing } \\
\text { Employment }\end{array}$ & $\begin{array}{r}\text { Share of } \\
\text { Manufacturing } \\
\text { Value Added }\end{array}$ & $\begin{array}{r}\text { Share of } \\
\text { Manufacturing } \\
\text { Sales } \\
\end{array}$ \\
\hline Manufacturing & $7,628.5$ & 958,032 & $3,232,355$ & & & \\
\hline Food & 700.6 & 88,555 & 294,643 & $9.2 \%$ & $9.1 \%$ & $9.2 \%$ \\
\hline Beverages and tobacco products & 173.2 & 30,825 & 66,028 & $3.2 \%$ & $2.0 \%$ & $2.3 \%$ \\
\hline \multicolumn{7}{|l|}{ Textiles, apparel, and leather } \\
\hline products & 171.2 & 9,779 & 27,633 & $1.0 \%$ & $0.9 \%$ & $2.2 \%$ \\
\hline Wood products & 76.1 & 9,086 & 28,126 & $0.9 \%$ & $0.9 \%$ & $1.0 \%$ \\
\hline Paper & 308.7 & 34,916 & 98,547 & $3.6 \%$ & $3.0 \%$ & $4.0 \%$ \\
\hline \multicolumn{7}{|l|}{ Printing and related support } \\
\hline Petroleum and coal products & 215.3 & 120,635 & 568,494 & $12.6 \%$ & $17.6 \%$ & $2.8 \%$ \\
\hline Chemicals & 898.9 & 159,133 & 449,113 & $16.6 \%$ & $13.9 \%$ & $11.8 \%$ \\
\hline Plastics and rubber products & 269.6 & 22,827 & 64,481 & $2.4 \%$ & $2.0 \%$ & $3.5 \%$ \\
\hline Nonmetallic mineral products & 138.4 & 13,181 & 37,808 & $1.4 \%$ & $1.2 \%$ & $1.8 \%$ \\
\hline Primary and fabricated metals & 554.9 & 55,590 & 163,217 & $5.8 \%$ & $5.0 \%$ & $7.3 \%$ \\
\hline Machinery & 563.1 & 51,728 & 160,767 & $5.4 \%$ & $5.0 \%$ & $7.4 \%$ \\
\hline Computers and electronic products & 823.0 & 98,589 & 281,549 & $10.3 \%$ & $8.7 \%$ & $10.8 \%$ \\
\hline \multicolumn{7}{|l|}{ Electrical equipment, appliances, } \\
\hline Transportation equipment & $1,857.9$ & 190,970 & 806,974 & $19.9 \%$ & $25.0 \%$ & $24.4 \%$ \\
\hline Furniture and related products & 124.5 & 8,004 & 22,375 & $0.8 \%$ & $0.7 \%$ & $1.6 \%$ \\
\hline \multirow[t]{3}{*}{ Miscellaneous manufacturing } & 335.8 & 32,778 & 78,285 & $3.4 \%$ & $2.4 \%$ & $4.4 \%$ \\
\hline & \multicolumn{6}{|c|}{ Matched Multinational Manufacturers } \\
\hline & $\begin{array}{l}\text { Employment } \\
\text { (Thousands) }\end{array}$ & $\begin{array}{r}\text { Value } \\
\text { Added } \\
(\$ \text { Millions })\end{array}$ & $\begin{array}{r}\text { Sales } \\
(\$ \text { Millions })\end{array}$ & $\begin{array}{r}\text { Share of } \\
\text { Manufacturing } \\
\text { Employment }\end{array}$ & $\begin{array}{r}\text { Share of } \\
\text { Manufacturing } \\
\text { Value Added }\end{array}$ & $\begin{array}{r}\text { Share of } \\
\text { Manufacturing } \\
\text { Sales }\end{array}$ \\
\hline Manufacturing & $6,445.7$ & 850,278 & $2,892,977$ & & & \\
\hline Food & 669.1 & 85,613 & 281,466 & $10.4 \%$ & $10.1 \%$ & $9.7 \%$ \\
\hline Beverages and tobacco products & 167.8 & 29,926 & 63,021 & $2.6 \%$ & $3.5 \%$ & $2.2 \%$ \\
\hline Textiles, apparel, and leather & & & & & & \\
\hline $\begin{array}{l}\text { products } \\
\text { Wood products }\end{array}$ & $\begin{array}{l}55.6 \\
73.7\end{array}$ & $\begin{array}{l}3,068 \\
8,870\end{array}$ & $\begin{array}{r}9,891 \\
27,528\end{array}$ & $\begin{array}{l}0.9 \% \\
1.1 \%\end{array}$ & $\begin{array}{l}0.4 \% \\
1.0 \%\end{array}$ & $\begin{array}{l}0.3 \% \\
1.0 \%\end{array}$ \\
\hline Paper & 241.8 & 28,549 & 81,831 & $3.8 \%$ & $3.4 \%$ & $2.8 \%$ \\
\hline Printing and related support & & & & & & \\
\hline activities & 167.4 & 11,135 & 21,563 & $2.6 \%$ & $1.3 \%$ & $0.7 \%$ \\
\hline Petroleum and coal products & 211.2 & 119,705 & 564,863 & $3.3 \%$ & $14.1 \%$ & $19.5 \%$ \\
\hline Chemicals & 725.2 & 137,791 & 377,052 & $11.3 \%$ & $16.2 \%$ & $13.0 \%$ \\
\hline Plastics and rubber products & 213.5 & 18,674 & 52,074 & $3.3 \%$ & $2.2 \%$ & $1.8 \%$ \\
\hline Nonmetallic mineral products & 107.9 & 9,176 & 29,358 & $1.7 \%$ & $1.1 \%$ & $1.0 \%$ \\
\hline Primary and fabricated metals & 421.7 & 43,123 & 120,369 & $6.5 \%$ & $5.1 \%$ & $4.2 \%$ \\
\hline Machinery & 432.5 & 40,923 & 130,318 & $6.7 \%$ & $4.8 \%$ & $4.5 \%$ \\
\hline Computers and electronic products & 631.9 & 80,483 & 218,687 & $9.8 \%$ & $9.5 \%$ & $7.6 \%$ \\
\hline $\begin{array}{l}\text { Electrical equipment, appliances, } \\
\text { and components }\end{array}$ & 199.9 & 16,338 & 51,707 & $3.1 \%$ & $1.9 \%$ & $1.8 \%$ \\
\hline Transportation equipment & $1,769.8$ & 184,690 & 785,814 & $27.5 \%$ & $21.7 \%$ & $27.2 \%$ \\
\hline Furniture and related products & 111.2 & 7,344 & 20,054 & $1.7 \%$ & $0.9 \%$ & $0.7 \%$ \\
\hline Miscellaneous manufacturing & 245.3 & 24,868 & 57,381 & $3.8 \%$ & $2.9 \%$ & $2.0 \%$ \\
\hline
\end{tabular}


Table 5: Geographic Location of Non-Bank Majority-Owned Foreign Affiliates (MOFAs)

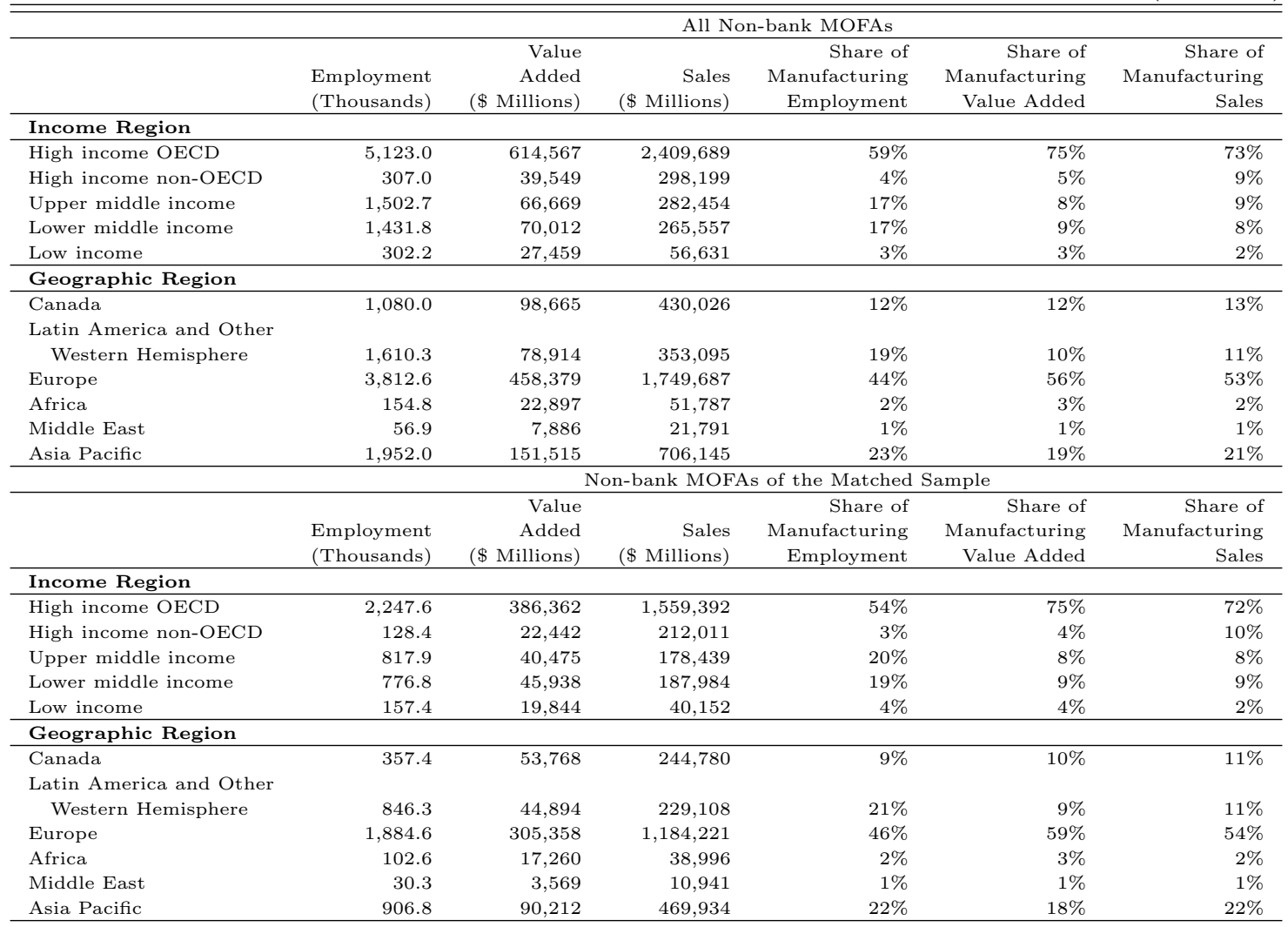




\section{Task Index by SOC Occupations, by Task}

\begin{tabular}{llc} 
Automation/Routinization Tasks: Top and Bottom Ten Six-Digit SOC Occupations \\
\hline \hline SOC code & SOC Title & Index \\
\hline 439021 & Data Entry Keyers & 0.15927 \\
516051 & Sewers, Hand & 0.13674 \\
516042 & Shoe Machine Operators and Tenders & 0.13616 \\
499093 & Fabric Menders, Except Garment & 0.13559 \\
537063 & Machine Feeders and Offbearers & 0.13266 \\
516031 & Sewing Machine Operators & 0.12091 \\
472043 & Floor Sanders and Finishers & 0.11993 \\
439071 & Office Machine Operators, Except Computer & 0.11909 \\
519041 & Extruding, Forming, Pressing, and Compacting Machine & 0.1178 \\
& Setters, Operators, and Tenders & \\
519197 & Tire Builders & 0.11642 \\
$\cdot$ & & \\
. & & \\
193041 & & 0.00826 \\
212099 & Sociologists & 0.00785 \\
251061 & Religious Workers, All Other & 0.00735 \\
251062 & Anthropology and Archeology Teachers, Postsecondary & 0.00735 \\
& Area, Ethnic, and Cultural Studies Teachers, \\
251063 & Postsecondary & \\
251065 & Economics Teachers, Postsecondary & 0.00735 \\
251066 & Political Science Teachers, Postsecondary & 0.00735 \\
251067 & Psychology Teachers, Postsecondary & 0.00735 \\
251125 & Sociology Teachers, Postsecondary & 0.00735 \\
212011 & History Teachers, Postsecondary & 0.00735 \\
\hline & Clergy & 0.00496 \\
\hline
\end{tabular}


Face-to-Face Interaction Tasks: Top and Bottom Ten Six-Digit SOC Occupations

\begin{tabular}{lll}
\hline \hline SOC code & SOC Title & Index \\
\hline 211012 & Educational, Vocational, and School Counselors & 0.13189 \\
212011 & Clergy & 0.13107 \\
212099 & Religious Workers, All Other & 0.11418 \\
395092 & Manicurists and Pedicurists & 0.10505 \\
399031 & Fitness Trainers and Aerobics Instructors & 0.1045 \\
211023 & Mental Health and Substance Abuse Social Workers & 0.10019 \\
252041 & Special Education Teachers, Preschool, Kindergarten, & 0.09777 \\
& and Elementary School & \\
252042 & Special Education Teachers, Middle School & 0.09777 \\
252043 & Special Education Teachers, Secondary School & 0.09777 \\
399021 & Personal and Home Care Aides & 0.09749 \\
$\cdot$ & & \\
. & & \\
512023 & & 0.00281 \\
514111 & Electromechanical Equipment Assemblers & 0.00269 \\
514031 & Tool and Die Makers & 0.00238 \\
517021 & Cutting, Punching, and Press Machine Setters, & \\
512011 & Operators, and Tenders, Metal and Plastic & 0.00233 \\
519083 & Furniture Finishers & 0.00098 \\
492091 & Aircraft Structure, Surfaces, Rigging, and Systems & \\
516051 & Assemblers & 0 \\
173024 & Ophthalmic Laboratory Technicians & 0 \\
512021 & Avionics Technicians & 0 \\
\hline & Sewers, Hand & 0 \\
& Electro-Mechanical Technicians & 0 \\
\hline
\end{tabular}


Information Content-Related Tasks: Top and Bottom Ten Six-Digit SOC Occupations

\begin{tabular}{lll}
\hline \hline SOC code & SOC Title & Index \\
\hline 439199 & Office and Administrative Support Workers, All Other & 0.20573 \\
439111 & Statistical Assistants & 0.20573 \\
152091 & Mathematical Technicians & 0.20075 \\
152021 & Mathematicians & 0.19705 \\
152041 & Statisticians & 0.17836 \\
193021 & Market Research Analysts & 0.1708 \\
152099 & Mathematical Scientists, All Other & 0.16749 \\
192011 & Astronomers & 0.16408 \\
232093 & Title Examiners, Abstractors, and Searchers & 0.1629 \\
434041 & Credit Authorizers, Checkers, and Clerks & 0.15762 \\
$\cdot$ & & \\
$\cdot$ & & \\
475081 & & \\
499045 & Helpers-Extraction Workers & 0.02425 \\
472073 & Refractory Materials Repairers, Except Brickmasons & 0.02409 \\
& Operating Engineers and Other Construction Equipment & 0.02397 \\
537033 & Operators & \\
513023 & Loading Machine Operators, Underground Mining & 0.02341 \\
419012 & Slaughterers and Meat Packers & 0.02295 \\
472043 & Models & 0.02278 \\
393093 & Floor Sanders and Finishers & 0.02192 \\
472221 & Locker Room, Coatroom, and Dressing Room Attendants & 0.02162 \\
537081 & Structural Iron and Steel Workers & 0.01889 \\
& Refuse and Recyclable Material Collectors & 0.01834 \\
\hline & & \\
& & \\
& & \\
& &
\end{tabular}




\section{Description of Variables and Data Sources for FDI Vari- ables}

\begin{tabular}{|c|c|c|}
\hline Variable Name & Source & Description \\
\hline Global Scope & $\begin{array}{l}\text { BEA and World } \\
\text { Bank }\end{array}$ & $\begin{array}{l}\left\{\sum_{C}\left(G_{U S}-G_{c}\right) \frac{y_{c}}{y_{w w}}\right\} * R \text {, where } C \text { is the set of } \\
\text { countries is which a parent company operates, } \\
G_{U S} \text { is per-capita income in the United States, } \\
G_{C} \text { is the per-capita income in country } c \epsilon C, y_{c} \text { is } \\
\text { employment in country } c, y_{W W} \text { is the parent } \\
\text { company's world-wide employment, and } \mathrm{R} \text { is the } \\
\text { number of geographic regions in which a parent } \\
\text { company operates. We divide the world into six } \\
\text { regions: North America, Central and South } \\
\text { America, Europe, Middle East, Africa, and Asia. }\end{array}$ \\
\hline $\begin{array}{l}\text { Exports to Foreign } \\
\text { Affiliates for Further } \\
\text { Processing }\end{array}$ & BEA & $\begin{array}{l}\text { Exports from U.S. parent to foreign affiliate of } \\
\text { goods intended for further processing, assembly, } \\
\text { or manufacture, measured at the affiliate level. }\end{array}$ \\
\hline $\begin{array}{l}\text { Exports to Foreign } \\
\text { Affiliates for Resale }\end{array}$ & BEA & $\begin{array}{l}\text { Exports from U.S. parent to foreign affiliate of } \\
\text { goods for resale, measured at the affiliate level. }\end{array}$ \\
\hline $\begin{array}{l}\text { Other Exports to } \\
\text { Foreign Affiliates }\end{array}$ & BEA & $\begin{array}{l}\text { All other exports of goods from U.S. parent to } \\
\text { foreign affiliate, measured at the affiliate level. }\end{array}$ \\
\hline $\begin{array}{l}\text { Imports from Foreign } \\
\text { Affiliates }\end{array}$ & BEA & $\begin{array}{l}\text { Imports of goods from the foreign affiliate to the } \\
\text { U.S. parent, measured at the affiliate level. }\end{array}$ \\
\hline
\end{tabular}




\section{E Description of Variables and Data Sources for Labor De- mand Regressions}

\begin{tabular}{|c|c|c|}
\hline Variable Name & Source & Description \\
\hline $\begin{array}{l}\text { Log Domestic } \\
\text { Task-Level Employment }\end{array}$ & $\begin{array}{l}\text { Matched } \\
\text { Dataset }\end{array}$ & $\begin{array}{l}\text { Firm-level domestic employment in each task as } \\
\text { determined by the task index. }\end{array}$ \\
\hline $\begin{array}{l}\text { Log Domestic } \\
\text { Task-Level Wage }\end{array}$ & $\begin{array}{l}\text { May and } \\
\text { November } 2004 \\
\text { OES }\end{array}$ & $\begin{array}{l}\text { Hourly average wage paid to each task (weighted } \\
\text { by employment in each occupation), at the } \\
\text { 4-digit NAICS industry level. }\end{array}$ \\
\hline Log Foreign Wage & BEA & $\begin{array}{l}\text { Annual salary paid to each foreign employee (at } \\
\text { the affiliate level), averaged at the } 4 \text {-digit NAICS } \\
\text { industry level weighted by employment, } \\
\text { calculated separately for all foreign affiliates, } \\
\text { affiliates in high-income countries, and affiliates } \\
\text { in low-income countries. }\end{array}$ \\
\hline R\&D Price & BEA & $\begin{array}{l}\text { Proxied by research and development spending at } \\
\text { the affiliate level as a share of total parent sales, } \\
\text { calculated separately for all affiliates, affiliates in } \\
\text { high-income countries, and affiliates in } \\
\text { low-income countries. }\end{array}$ \\
\hline U.S. Investment Price & $\begin{array}{l}\text { NBER } \\
\text { Manufacturing } \\
\text { Database }\end{array}$ & $\begin{array}{l}\text { Variable named PIINV, which is the deflator for } \\
\text { new investment flows. }\end{array}$ \\
\hline $\begin{array}{l}\text { Foreign Investment } \\
\text { Price }\end{array}$ & $\begin{array}{l}\text { Penn World } \\
\text { Tables } 8.0\end{array}$ & $\begin{array}{l}\text { PPP price of domestic investment in the country } \\
\text { in question. }\end{array}$ \\
\hline $\begin{array}{l}\text { Domestic Consumer } \\
\text { Goods Price }\end{array}$ & BEA, BLS & $\begin{array}{l}\text { Log of industry sales from the BEA parent } \\
\text { survey deflated by the producer price index from } \\
\text { the BLS, at the } 4 \text {-digit NAICS industry level. }\end{array}$ \\
\hline $\begin{array}{l}\text { Foreign Consumer } \\
\text { Goods Price }\end{array}$ & $\begin{array}{l}\text { BEA, Penn } \\
\text { World Tables } \\
8.0\end{array}$ & $\begin{array}{l}\text { Log of affiliate sales in the BEA affiliate surveys } \\
\text { deflated by the foreign price index in PWT 8.0. }\end{array}$ \\
\hline
\end{tabular}




\begin{tabular}{|c|c|c|}
\hline Variable Name & Source & Description \\
\hline U.S. Import Penetration & $\begin{array}{l}\text { Bernard et al. } \\
(2006)\end{array}$ & $\begin{array}{l}\text { Imports in the United States divided by imports } \\
\text { in the United States plus total production in the } \\
\text { United States minus exports from the United } \\
\text { States by } 4 \text {-digit NAICS. }\end{array}$ \\
\hline $\begin{array}{l}\text { U.S. Import Penetration } \\
\text { from Low-Income } \\
\text { Countries }\end{array}$ & $\begin{array}{l}\text { Bernard et al. } \\
(2006)\end{array}$ & $\begin{array}{l}\text { Imports in the United States divided by imports } \\
\text { in the United States plus total production in the } \\
\text { United States minus exports from the United } \\
\text { States by 4-digit NAICS for countries designated } \\
\text { as low-income by the World Bank. }\end{array}$ \\
\hline Firm Size & BEA & $\begin{array}{l}\text { Worldwide employment }=\text { Sum of parent } \\
\text { employment plus employment across all affiliates. }\end{array}$ \\
\hline Firm Age & BEA & $\begin{array}{l}\text { Proxied by number of years a firm participated in } \\
\text { the BEA surveys of direct investment abroad. }\end{array}$ \\
\hline Firm Industry & BEA & 3-digit NAICS code. \\
\hline
\end{tabular}

